2013

\title{
THE EFFECT OF EASTERN KENTUCKY COAL FIRES ON LOCAL AIR QUALITY AND PERSONAL HEALTH
}

Eric C. Abbott

Michigan Technological University

Follow this and additional works at: https://digitalcommons.mtu.edu/etds

Part of the Education Commons

Copyright 2013 Eric C. Abbott

\section{Recommended Citation}

Abbott, Eric C., "THE EFFECT OF EASTERN KENTUCKY COAL FIRES ON LOCAL AIR QUALITY AND PERSONAL HEALTH", Master's report, Michigan Technological University, 2013.

https://doi.org/10.37099/mtu.dc.etds/610

Follow this and additional works at: https://digitalcommons.mtu.edu/etds

Part of the Education Commons 


\title{
THE EFFECT OF EASTERN KENTUCKY COAL FIRES ON LOCAL AIR QUALITY AND PERSONAL HEALTH
}

\author{
By \\ Eric C. Abbott \\ A REPORT \\ Submitted in partial fulfillment of the requirements for the degree of \\ MASTER OF SCIENCE \\ in Applied Science Education
}

MICHIGAN TECHNOLOGICAL UNIVERSITY

2013

(C) Eric C. Abbott 2013 
This page deliberately blank 
This report The Effect of Eastern Kentucky Coal Fires on Local Air Quality and Personal Health has been approved in partial fulfillment for the requirements for the degree of MASTER OF SCIENCE in Applied Science Education

\section{DEPARTMENT OF COGNITIVE AND LEARNING SCIENCES}

$\begin{array}{ll}\text { Report Co-Advisor: } & \text { Kedmon Hungwe } \\ \text { Report Co-Advisor: } & \text { Bradley Baltensperger }\end{array}$

Committee Member: $\quad$ Linda Nagel

Department Chair: $\quad$ Bradley Baltensperger 
This page deliberately blank 


\section{Table of Contents}

Table of Contents.............................................................

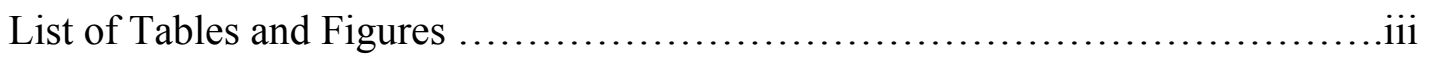

Abstract................................................................

Acknowledgements....................................................

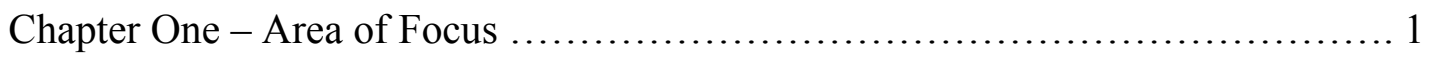

Introduction......................................................1

Rationale...................................................... 2

Content Standards ...............................................2

Chapter Two - Literature Review........................................ .7

Educational Basis and Framework.................................. 7

History of Coal Mining in Appalachia.................................8

Types of Coal Mines................................................ 10

Causes of Coal Fires.............................................11

Information about Specific Fires.................................. 12

Environmental Impact of Coal Fires.................................14

Human Health Impact of Coal Fires................................. 16

Extinguishing Coal Fires.......................................... 17

Chapter Three - Unit Design.............................................21

School/Student Background.......................................21

Review of Standards ............................................21

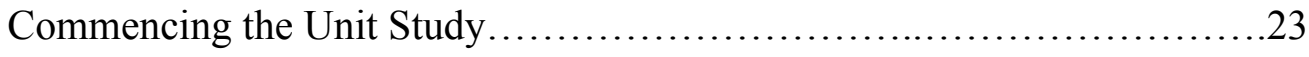


Narrative Summary of Lessons...................................25

Chapter Four - Presentation and Interpretation of Data..........................29

Pre- and Post- Test Comparison.....................................29

Pre-test (Formative Assessment) Analysis...........................30

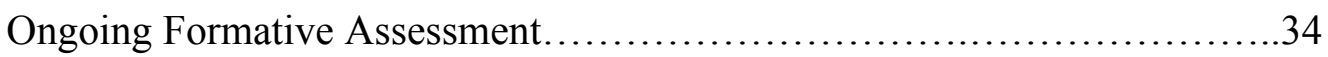

Post-test (Summative Assessment) Analysis.............................37

Chapter Five - Conclusions...........................................66

Overview of Research Results.......................................66

Limitations of Research.............................................67

Suggestions for Revision.........................................68

Appendix................................................................ 70

Coal Pretest...................................................71

Article Review Template........................................73

Coal and Coal Fire Internet Investigation.............................. 74

COAL Documentary Video Notes..................................... 76

Article Summary Directions....................................... 77

Coal and Coal Fires End of Unit Assessment................................. 78

Unit Plan......................................................... 81

References................................................................ 86 


\section{List of Tables and Graphs}

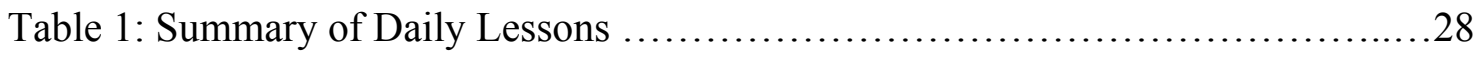

Table 2: Target Concepts and Test Questions................................. 30

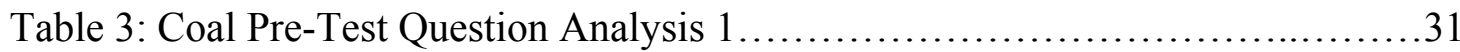

Table 4: Environmental Question Pre-Test Analysis 2 ........................... 32

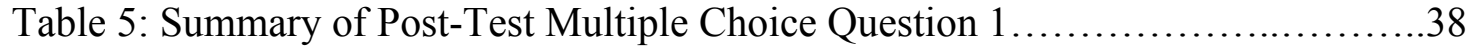

Table 6: Summary of Post-Test Multiple Choice Question 2.......................39

Table 7: Summary of Post-Test Multiple Choice Question 3......................40

Table 8: Summary of Post-Test Multiple Choice Question $4 \ldots \ldots \ldots \ldots \ldots \ldots \ldots \ldots \ldots . \ldots 40$

Table 9: Summary of Post-Test Multiple Choice Question 5.....................42

Table 10: Summary of Post-Test Multiple Choice Questions 6-7..................43

Table 11: Summary of Post-Test Multiple Choice Question 8.......................44

Table 12: Summary of Post-Test Multiple Choice Question 9......................45

Table 13: Summary of Post-Test Multiple Choice Question 10....................46

Table 14: Scoring Rubric for 4-Point Open Response Question....................48

Table 15: Scoring Rubric for 2-Point Open Response Question....................55

Table 16: Scoring Rubric for 5-Point Open Response Question .....................59

Graph 1: Percentage of Points Earned: Question $11 \ldots \ldots \ldots \ldots \ldots \ldots \ldots \ldots \ldots \ldots \ldots \ldots . \ldots . \ldots \ldots$

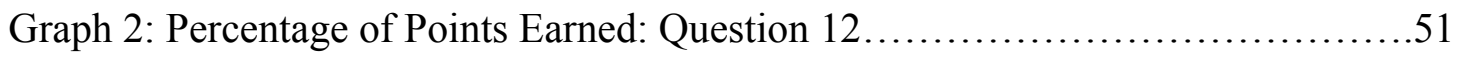

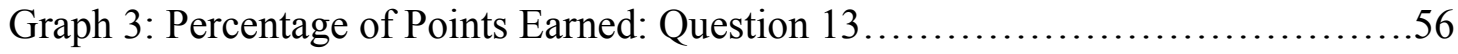

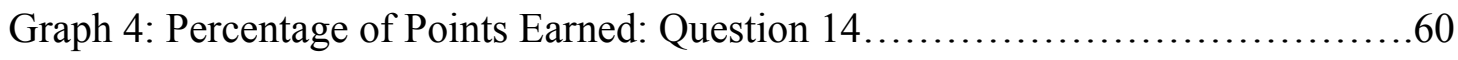




\begin{abstract}
A study of The Effect of Eastern Kentucky Coal Fires

on Local Air Quality and Personal Health

By
\end{abstract}

Eric C. Abbott

The purpose of this project was to investigate student learning in the areas of earth science and environmental responsibility using the subject of coal fires. Eastern Kentucky, where this study was performed, has several coal fires burning that affect the local air quality and may also affect the health of people living near them. This study was conducted during the regular education of $9^{\text {th }}$ grade Earth Science classroom in Russell Independent Schools, located in Russell, Kentucky. Students conducted internet research, read current articles on the subject of coal fire emissions and effect on local ecology, and demonstrated what they learned through summative assessments. There were several aspects of coalmines and coal fires that students studied. Students were able to take this knowledge and information and use it as a learning tool to gain a better understanding of their own environment. Using the local history and geology of coalmines, along with the long tradition of mine production, was a very beneficial starting point, allowing students to learn about environmental impact, stewardship of their local environment, and methods of preserving and protecting the ecosystem. 


\section{Acknowledgements}

There is no question that this project would not have been possible without the gracious help, support, encouragement, and guidance from the faculty and staff at Michigan Technological University. I would be remiss if I did not take the time to mention some very special people. A very sincere thank you goes to Dr. Baltensperger, who has supported me from the very beginning and throughout this entire process. To Dr. Hungwe, who has taken so much of his time to communicate details and answer all my questions with patience and tolerance, your help was invaluable - Thank you. To Judy Anderson and Nancy Byers Sprague, who so often sent reminders of deadlines, supported me, and was often a liaison on my behalf through out this project - Thank you. Several others at Michigan Tech were supportive and helpful also, too many to list. And finally, to my wife and family, for the time that I spent at the computer instead of playing catch, yatzee, or just snuggling on the chair. Without your understanding and support, this would have continued to be a failed effort. But thanks to everyone, it is finally a mission accomplished. 
This page deliberately blank 


\section{Chapter 1 - Area of Focus}

\section{Introduction}

"This was a world where no human could live, hotter than the planet Mercury, its atmosphere as poisonous as Saturn's. At the heart of the fire, temperatures easily exceeded 1,000 degrees [Fahrenheit]. Lethal clouds of carbon monoxide and other gases swirled through the rock chambers". (DeKok, 1986) This describes a coal fire in Centralia, PA, that has been burning since 1962. The heat, gasses, and total environmental impact of that coal fire caused the small town of Centralia to virtually disappear. Almost all buildings have been demolished over the past five decades, whether by natural dilapidation or by people, and according to the 2010 census, there were only 10 people who claimed to be residents of Centralia, down from over 1,000 in 1981. Such devastation can be the impact of large-scale coal fires.

The global distribution and occurrence of coal fires has risen since the industrial revolution. Anywhere on the planet where there is coal mining and coal industry, there exists potential for coal fires. The wide-reaching scope of coal fires ranges from Russia to South Africa, and even in the United States, specifically Eastern Kentucky (Stracher, 2009), which was the focus of this research. However, it is not only industry that can produce a coal fire. There are many different causes of coal fires. Mining and vegetation fires can cause coal fires. Natural occurrences such as lightning strikes can be responsible. Or even spontaneous combustion can bring out these air polluting events. There have been, and still are, thousands of what can be referred to as "coal seam" or "mine" fires globally. "Every coal basin in the world has fires sending up organic 
compounds that are not good for you," stated Mark Engle, a geologist with the U.S. Geological Survey (Cray, 2010.)

\section{Rationale}

This research focuses on student learning related to earth science. I have chosen to use coal fires as a platform for instruction in my classroom because my students live in the Appalachian Mountain region and have a relevant connection to coal production and related coal fires. Specifically, I have chosen to utilize some of the coal fires that were burning in the United States, and, more specifically, in Eastern Kentucky, through the year 2012. I have gathered emission gas data from studies on coal fires throughout America and related those findings to environmental, social, and economic impact. I also explore how the air quality in my geographic area has impacted the health of residents of Eastern Kentucky.

In the earth science curriculum at Russell High School where I taught, one important area of focus was related to earth's atmosphere and issues pertaining to atmospheric changes. I want to be able to take information from current and past studies to demonstrate to students how coals fires affected environmental quality. Furthermore, I desire to help my students explore the potential effects of changes in the environment on a person's health.

\section{Content Standards}

At the time of the research, I was teaching an Earth Science curriculum to $9^{\text {th }}$ grade students. Those students were in their first year of science education at the high school level, although they had been exposed to some concepts of earth science in middle 
school. The Kentucky Core Content for Science Assessment standards for high school science include the following standards related to the problem of coal fires:

SC-HS-4.7.2

Students will:

- evaluate proposed solutions from multiple perspectives to environmental problems caused by human interaction;

- justify positions using evidence/data.

Human beings live within the world's ecosystems. Human activities can deliberately or inadvertently alter the dynamics in ecosystems. These activities can threaten current and future global stability and, if not addressed, ecosystems can be irreversibly affected.

\section{SC-HS-4.7.3}

Students will:

- predict the consequences of changes to any component (atmosphere, solid Earth, oceans, living things) of the Earth System;

- propose justifiable solutions to global problems.

Interactions among the solid Earth, the oceans, the atmosphere and living things have resulted in the ongoing development of a changing Earth system.

The aforementioned standards drove the development of a unit of study directed at human and natural impact on the environment and possible effects on the local population. The first standard, SC-HS-4.7.2, set the stage for students to be able to identify and explain the problem of local coal fires as caused by human interaction with the environment. As students in a class investigated the problem of coal fires, I anticipated that they would approach the topic from varied perspectives and propose multiple solutions. As we researched the topic as a class, they learned of the current methods used to control and monitor coal fires, and it was my hope that students would propose different, and maybe even innovative, ideas for handling situations like coal fires.

Furthermore, student research and presentation of facts resulted in fulfillment of SC-HS-4.7.2 as students were required to present evidence and data to support their 
positions concerning coal fires. There was a great point-counterpoint opportunity related to the topic of coal fires. If nations didn't mine coal, then there would be no coal fires. However, if nations didn't mine coal, they would also not be utilizing a readily available energy source that is used locally for electric energy production. As arguments could be made both for and against the continuation of coal mining, a very interesting debate between students occurred.

The second standard that was addressed, SC-HS-4.7.3, was supported through the follow-up portion of the unit. This portion allowed students to see the consequences of what has happened as a result of coal mining. Knowing the results of past practices of mining, students were able to make predictions about the consequences of future actions related to coal mining, as well as make educated predictions concerning the next approach to controlling coal fires. It was my desire that students would generate theories that would venture into new methods relating to the mining industry as a whole.

As of 2012, there were several different types of industry in the Ohio Valley. I was living in Ashland, KY, a city at the juncture of Kentucky, Ohio, and West Virginia. Ashland was also the geographical point where two major river systems come together, with the Big Sandy River feeding into the Ohio River. This waterway juncture is well traveled in the shipping industry. There are also several industrial plants and mills in Ashland and the surrounding areas, including a steel mill, a coke (steel coke) plant, and an electric power plant, among others. Several of the plants burned coal for heat and energy. There was also a CSX train yard in Ashland, which made it a common daily occurrence to see over 100 cars carrying coal through town from the coal fields several miles away. The city where I taught actually hosted one of the largest coal sorting 
platforms along the rail line, as well as one of the biggest customers/consumers of coal in the Armco Steel plant (Dixon, 2006). Barges on the Ohio River also commonly carried tons of coal to the Mississippi shipping channels. Additionally, anyone could easily pass 20 semi trucks loaded with coal any day of the week driving along the highway. Bumper stickers that were commonly seen in Eastern Kentucky proclaimed, "Coal keeps the lights on," signifying the general support of the coal industry and the burning of coal as an energy source for the area.

In this study, I attempted to relate the environmental issues in and around the Eastern Kentucky area to coal fires and emission gasses of burning coal. Students often are unaware of the world around them. I had lived and taught in the Ashland area for three years, and no one had ever mentioned to me the coal fires that raged within an afternoon's drive from Ashland. It is likely that the average person was just unaware of what was happening, and that those who were aware, such as workers in fields related to the coal industry, just accepted it as part of everyday life.

It was my hope that my students would gain more interest in their surroundings by becoming more aware of the air they breathed each day. Air quality differs so greatly in just a few miles from any given location; I believed it would be fascinating to discover how the quality of air, and therefore possibly the quality of life, might be affected by the wide range of atmospheric measurements in and around the Ashland area. For example, in a county just south of where I lived, there was a coal fire that had been burning for some time. One specific study took samples of some of the byproducts of the burning coal. An analysis of the samples indicated toxic levels of Benzene and Toluene according to NIOSH for an 8-hour exposure. 
My research on coal fires and air quality correlated with, as well as enhanced, the established science curriculum at my school. In my earth science class, there were sections where students learned about the atmosphere. Students learned about the chemical composition of the air they breathed and some of the pollutants that were found in the air. Sources of pollution were covered as well as pollution's effects on people and the environment. 


\section{Chapter 2 - Literature Review}

\section{Educational Basis and Framework}

The book Teaching for Understanding defines "understanding" in general terms as, "The ability to think and act flexibly with what one knows." (p.40) Furthermore, the Teaching for Understanding framework and the research behind it also emphasized hands-on, concrete, meaningful learning experiences rather than inundating students with large amounts of vocabulary and rote facts to memorize. It was my desire that the students would take knowledge from the classroom and apply it to life experiences. Someone sitting in my classroom might be the person to invent an innovative technology that would forever change the coal industry. Another of my students may grow up to design a method for eliminating coal fires, and thus improve the environment for generations to come.

The American Association for the Advancement of Science (AAAS) described the science and math curriculum of most schools as, "overstuffed and undernourished," meaning that emphasis tended to be on learning answers rather than exploring questions, memory at the expense of critical thinking, and gaining bits and pieces of information rather than gaining understanding of material in context. (Project 2061 - Science for All Americans, 1990) In designing the lessons and activities throughout the coal unit, I used the council's recommendations that students should be able to work together, that they should be allowed to freely share information and ideas, that learning is more meaningful when it is "hands-on," and that students should use current technology to extend their intellectual capabilities. 
The AAAS also stated that, "Science, energetically pursued, can provide humanity with the knowledge of biophysical environment and of social behavior needed to develop effective solutions to its global and local problems; without that knowledge, progress toward a safe world will be unnecessarily handicapped." (Project 2061 Science for All Americans, 1990) Helping students gain a greater understanding of the coal industry and the nature of coal fires could have far-reaching future effects on both the coal industry in the United States and other countries, as well as widespread impact on the future of earth's environment. If this generation learns more about the impacts and hazards of the coal industry because of the industry's current practices, they may be able to change mining practices in the future, and therefore be able to reduce the amount of environmental and personal dangers and deaths compared to what is common today.

While coal and coal fires would be a beneficial topic for students anywhere to learn, it was especially relevant to students in my school district and surrounding districts because coal and coal related industries were a part of everyday life. All of the students, as well as every person who lived in the Ashland area, were affected by the environmental impact of coal related productions and processes to some extent. Furthermore, it was very likely that a significant percentage of my students would work in the coal industry after they left high school, whether it was directly in the coal mines, in a coal powered plant, as an engineer designing new processes for extracting and utilizing coal, or on the railroads loading and transporting coal to be used all over the nation.

\section{History of Coal Mining in the Appalachian Area}


Coal is one of the most abundant and utilized resources in the area of the United States where I lived. From coal burning stoves in homes to coal-powered plants that provided power to hundreds of thousands of people, coal had a far-reaching impact on the lives of every citizen in eastern Kentucky. Coal was actually discovered in Virginia in 1701, and 1748 marked the first recorded large-scale coal production (History of Coal) In Kentucky, the first commercial mine, the McLean Drift Bank, was opened in Muhlenberg County in 1820, and 328 short tons were mined and sold in Kentucky that year. Ten years later, production had grown exponentially, with 2000 tons produced in 1830 . Improved production methods and larger scale mine operations led to 100,000 tons being produced in 1843. In 1990, Kentucky had a record-breaking production year of 179.4 million tons produced.

One popular form of coal mining in Kentucky is strip mining. Strip mining is done where deposits of coal were close to the surface, and the mountaintops were literally sheared away to expose the coal veins. Often the strip mine site is left bare, causing problems with run-off waters and erosion. However, in 1977, the Surface Mining Control and Reclamation Act required that lands be returned to original contours as much as possible and that vegetation be replaced (Torok, 2004).

Coal exists in various forms, such as lignite, bituminous coal and anthracite coal. As peat is pressurized it forms lignite coal. As pressure increases over time, lignite turns into bituminous coal, which is sometimes referred to as soft coal. Extremely high pressures or temperatures will turn bituminous coal to anthracite coal, which is sometimes called hard coal. At the time of my research, most coal being mined in Eastern Kentucky, commonly referred to as the Big Sandy region, was bituminous coal. "Most of 
the bituminous coals in the Big Sandy region are low sulfur, low ash, low volatile coal." (Torok, 2004).

\section{Types of Coal Mines}

By the late nineteenth and early twentieth centuries, there were three types of mines being operated in the Big Sandy region. The first and most common was the drift mine, where a coal seam was reached by digging horizontally into the side of a mountain. As the mines were located above the valley floor, they were the easiest and least expensive to operate, as men were able to walk directly into the mine and utilize horses, mules, and later, small locomotives to transport the coal out of the mine and down the mountain.

Another type of mine was a slope mine. In slope mining, an inclined entrance was dug to reach a coal seam that was located below the surface, but not necessarily at a great depth. Early slope mines were more expensive and difficult to construct. Therefore they were not as popular until the twentieth century, when locomotives and conveyers made slope mining easier.

A third type of mine in the Big Sandy region was a shaft mine. To mine coal seams that were further below the surface, a vertical shaft was dug, with miners and equipment having to be lowered to the work site with elevators or hoists. Due to higher costs of equipment and the increased technology required to raise workers and mined coal to the surface, there were not many shaft mines in the early days of coal mining in the Big Sandy region. However, as the need to dig deeper to find coal as surface deposits were depleted, and with an increase in knowledge and more readily available and affordable technology, shaft mining became more common. 


\section{Causes of Coal Fires}

Wherever there is coal, there will be coal fires. Coal fires are a major problem not only for coal miners and the land immediately surrounding the coalmine, but also for the environment at large. "One of the most frequent and serious causes of coal fires is spontaneous combustion. Given the right kind of coal, oxygen, and a certain temperature and moisture content, coal will burn by itself." (The Fire Below, 1993) Excessive storage times of coal can generate increased heat. Also, when coal is compacted, and particles become smaller, they become more combustible. When exposed to oxygen, such as cases where coal slag and dust is stirred up after a long time period, coal can become highly volatile, and subject to spontaneous combustion. Moisture content also plays a major role; moisture contributes to spontaneous heating because it assists in the oxidation process.

Other fires are caused due to natural causes such as lightning strikes and ignition due to existing ground and vegetation fires. This occurs where the coal seam itself is closer to the surface of the ground or where other processes, such as digging a pit, expose coal to the environment.

Sometimes coal fires are the result of human-related activities. For example, one of the most famous coal fires, the Centralia fire, was a result of someone burning a pile of rubbish in the town dump. This fire became such a problem that between 1980 and 1998, the whole city had to be evacuated and relocated. (Kuenzer, 2007) At the time of my research, the Centralia fire was still burning. Other fires have been a result of actions occurring during the mining of coal. Once burning, coal fires can burn for decades or even hundreds of years. 
Ann G. Kim refers to coal fires from human related activities or natural causes as "forced" ignition fires. (Coal and Peat Fires: A Global Perspective Volume I, 2011). Information About Specific Fires

The oldest documented coal fire has been burning for over 2000 years in New South Wales, Australia. Coal fires in China are also mentioned in historic documents as early as the year 1000. (Kuenzer, 2007) At the time of this research, 2012, there were hundreds of other coal fires throughout the world. Some very problematic coal fires were burning in the United States, with a significant number near the Big Sandy region.

A few of the most well-known coal fires in the Appalachian area of Eastern Kentucky included the Tiptop fire, the Ruth Mullins, the Laura Campbell fire, and Old Smokey. Commonly, the name that was given to a coal seam fire was the name of the person who first officially discovered it. Once in a while, however, a coal seam fire was given a more generic name, as is the case with Old Smokey.

As of 2009, there were 6 active or recently active coal fires burning in Kentucky. Concerns that, "Coal fires consume coal resources, pollute the environment, and emit potentially toxic gasses" (Hower et. al, 2009) prompted a study of the Tiptop coal mine fire that had been burning in northern Breathitt county Kentucky for numerous years. Although the exact date and cause of the fire are unknown, some sources believed that it could have been burning as early as the 1930s.

The Ruth Mullins Fire became a severe respiratory hazard to nearby residents, as well as threatening Kentucky Route 80. It is theorized that the Ruth Mullins Fire was attributable to the geologic action of subsidence. This subsidence could have happened when coal was removed from abandoned mining tunnels beneath the road in 1980. The 
collapse of the land above the coal mine likely caused exposure of the coal seam to moisture and oxygen, which in turn contributed to the ignition of the fire.

The Laura Campbell Fire was a good example of how coal fires may start naturally. This particular fire was thought to have started by spontaneous combustion, the process where just the right combination of heat, coal, and other factors increased the temperature of the coal to its ignition point, causing the coal to burn. The more difficult problem with these types of situations has been that no one may be aware that a fire has started until the smoke begins to finally seep out of the ground. By that time the coal fire is well involved, sometimes so involved that it is beyond any simple means of extinguishment.

Yet another fire burning in Eastern Kentucky at the time of my research was Old Smokey, which had been burning for numerous years in Floyd County Kentucky. A team of scientists studied the vent emissions from Old Smokey in May and July of 2010. The gasses from this mine fire were venting through rock fill that was placed around the mine when it was abandoned. Readings were taken periodically at several sites. Each reading showed different concentrations of gas emissions, probably due to the ever-changing and unpredictable nature of the fire. The emissions from the vents included over 45 volatile organic compounds, some of which were, "toxic, carcinogenic, mutagenic, and hallucinogenic." (O’Keefe, et al. 2011)

\section{Environmental Impact of Coal Fires}

Coal fires have detrimental effects on the environment and structures built by people. They pollute the biosphere, hydrosphere, atmosphere, and lithosphere with by-

products of combustion. (Stracher, et. al, 2009) Ann G. Kim concurred, noting that, "Coal 
fires in abandoned mines, in waste banks, and in un-mined outcrops constitute serious safety and environmental hazards." (Coal and Peat Fires, Volume I, 2011) Kim went on to delineate land subsidence, a deterioration in air quality, depressed property values in and around the affected areas as just a few of the concerns related to coal seam fires. Gas chromatographic readings have shown that carbon monoxide, benzene, toluene and many other toxins are released into the air and soil as a result of burning coal fires. Furthermore, the greenhouse gasses methane and carbon dioxide as well as the ozoneforming gasses ethane, propene, and propane are also produced.

An environmental impact study was conducted at the Tiptop coalmine fire. The study found that all of the $\mathrm{CO}$ and $\mathrm{CO}_{2}$ measurements far exceeded the eight-hour OSHA exposure limit. Furthermore, the Hg values, "exceed the recommended exposure limit and are several orders of magnitude higher than background tropospheric $\mathrm{Hg}$ concentrations ( $1.5 \mathrm{ng} / \mathrm{m} 3)$ )" (Hower et al., 2009) In addition to $\mathrm{CO}, \mathrm{CO}_{2}$, and $\mathrm{Hg}$, gas analysis of the emissions from the Tiptop fire also indicated the presence of a wide range of volatile organic and carbon-sulfur compounds that were hazardous to the environment and to humans.

In China, it is estimated that 20-30 million tons of coal burn in fires each year, resulting in economic loss and great environmental impact. At the time of my research, a current estimate was that coal fires in China contributed about $0.1 \%$ to $0.2 \%$ of the annual human induced carbon dioxide emissions globally.

Thousands of hidden fires smolder and rage through the world's coal deposits, quietly releasing gases that can ruin health, devastate communities, and heat the planet. Some of the toxic gasses released include carbon dioxide, methane, nitrogen oxides, 
nitrous oxide, carbon monoxide, and sulfur dioxide. All of the emissions are detrimental to the environment and can affect human health.

Coal fires have forever changed the geology of the lands near the Emory coalfield in Utah, the Jharia coalfield in India, and the Ningxia coalfield in China. (Stracher, et. al, 1997) One geologic environmental impact of coal fires is land subsidence. Many times the problematic coal fire is below the surface of the ground. The depth of the fire can vary because the fire follows the coal vein itself, and coal veins do not follow straight lines underground. As the coal is burned away, there is a large cavity underground where the coal was. Ultimately, the ground above can, and often does, collapse, leaving a large crater in the ground. Sometimes this happens on the side of a mountain where it does not truly impact the everyday lives of the local population. However, sometimes it can happen directly under a road. In these cases, the road will crack and collapse, and the road cannot be fixed or patched because of the large cavern underground where the coal once was.

"Minerals (from coal fire emissions) will sublimate on virtually any available surface, including the roots of trees exposed in the fissures in the fracturing and slumping mountain (surrounding the Ruth Mullins fire). Tars are even more opportunistic, condensing on rocks, fire related minerals, leaves, icicles and spider webs." (Hower and O'Keefe, 2010).

The impact of coal fires can be far-reaching. Pollutants from China's coalfields were found to have contributed to acid rain as far away as the Philippines, Japan, and Korea. It is very possible that local coal fires may impact the United States far away from Eastern Kentucky, also. 


\section{Human Health Impact of Coal Fires}

"Although the global-annual emissions of the components in coal-fire gas have never been quantified, the toxins from fires burning around the world have made people sick, sometimes culminating in death." (Stracher et. al., 2009) Around the world cases of carbon monoxide poisoning, stroke, lung cancer, bronchitis, pulmonary heart disease, arsenosis, and fluorosis have been documented and attributed to coal fire emissions and by-products.

The elements arsenic, fluorine, mercury, and selenium are naturally occurring in coal. As coal is burned, these elements become volatile, and can condense in toxic concentrations on dust particles that are inhaled by humans and livestock. Furthermore, research suggests that toxic concentrations of harmful coal byproducts can also contaminate the food chain by absorption on food crops and bioaccumulation in the systems of fish, birds, and other animals. (Stracher, et. al., 2009)

A wide variety of organic and carbon-sulfur compounds are found in the emissions of coal fires. One known carcinogen is benzene, which has been linked to several forms of leukemia, Hodgkin's disease, multiple myeloma, and non-Hodgkin's lymphoma. (Agency for Toxic Substances and Disease Registry, 2000, as cited in Hower et al., 2009)

The negative health impacts have even threatened water supplies, as was the case with the Laura Campbell fire. Gas analysis revealed the presence of 47 potentially toxic compounds emitted into the atmosphere as well as surface deposits of creosote, sulfur, and ammonia compounds, which are soil and water pollutants. 
In the Jharia coalfield, poor miners and their families lived in villages that were precariously close to the multiple burning fires. Water, soil, and air were polluted with toxic ash and vapors, resulting in increased instances of human diseases including asthma, chronic bronchitis, lung cancer, and skin cancer. The workers' houses were also often damaged due to fire-induced ground subsidence.

\section{Extinguishing Coal Fires}

Extinguishing coal fires is a daunting task for many reasons. First of all, the sheer amount of coal (sometimes hundreds of tons) makes it difficult to get to the heart of the fire itself. Furthermore, coal that is in the flaming or smoldering stage emits large amounts of methane and carbon monoxide, which are both highly toxic as well as highly explosive in certain concentrations. (The Fire Below, 1993)

One method that has been used to combat coal fires was to isolate the fire from its fuel source. For example, fire breaks or fireproof barriers might be installed. Or, the flow of oxygen, which was needed for the fire to continue to burn, was cut off by completely covering the area or installing gas-tight barriers. However, these methods were only found to be useful if the fire was located close to the surface, or was in a relatively small area.

Generally water is used to combat many types of fires. However, the situation was found to be more complicated when the fire involved coal; due to the possibility of a steam explosion, water needed to be applied carefully and from a safe distance, complicating the fire-fighting efforts. Furthermore, if any dry coal absorbed the water, the resulting heat of absorption could cause a re-ignition of a once-quenched area as the area dried. 
At the time of this research China had experienced some of the longest burning as well as numerous and far-reaching coal fires in history. Chinese scientists and engineers in the coal production industry had also developed a unique method for extinguishing near-surface coal seam fires which involved the following steps:

- Smoothing the surface above the fire with heavy equipment to make it fit for traffic.

- Drilling holes in the fire zone about $20 \mathrm{~m}$ apart down to the source of the fire, following a regular grid.

- Injecting water or mud in the boreholes long term, usually 1 to 2 years.

- Covering the entire area with an impermeable layer about $1 \mathrm{~m}$ thick, e.g., of loess.

- Planting vegetation to the extent the climate allows.

Efforts are underway to improve upon and refine the Chinese method, such as introducing additives to the quenching water or using alternative extinguishing agents.

Extinguishing underground coal fires in mines is a much more difficult and dangerous proposition. Mine personnel attempt to isolate the area by building dams and galleries. Then an inert gas such as nitrogen is introduced to the fire, via pipelines. However, because of the intense heat and toxic emissions from coal fires, sometimes it is not even possible to attempt such intervention due to the danger to workers.

The U. S. Department of Energy is responsible for overseeing the coal-powered energy plants around the country. They reported instances of spontaneous combustion in coal within the storage areas for the coal as well as in the bunkers of the plants themselves. In 1992 a fire resulting from spontaneous combustion was reported. Workers initially attempted to extinguish the fire by removing coal from the bunker by feeding it rapidly into a boiler and using a drag chain to move it out to a field. However, the drag 
chain failed after 30 minutes. Workers then attempted to apply carbon dioxide, which was unsuccessful. At one point, flames were shooting 75 feet above the base of the hot spots where the fire began. Workers were hesitant to use water to fight the flames due to the possibility of a steam explosion; however, after other efforts failed, water was applied without incident, and the fire was finally extinguished 28 hours after it began. (The Fire Below, 1993)

Other efforts have been employed to extinguish coal fires. Instead of flooding coal seams with water, which, depending on the size of the coal mine, can be a very daunting task, workers would try using chemicals such as carbon dioxide or nitrogen to mitigate the effects of coal fires. It proves much easier to flood an open coalmine with a gas than a liquid, and choosing a non-flammable gas seemed a good choice to attempt to smother the fire. However, after several documented trials, the U. S. Department of Energy reported mixed results from those efforts. (The Fire Below 1993)

Reviewing the literature addressing coal fires throughout the United States and the rest of the world brought into focus the vast impact that coal fires have on society. It was my hope that students who learned about these impacts would be better able to make scientific, and maybe more importantly, personal decisions, that are environmentally responsible.

The impact of coal fires has had far reaching effects on the environment and society. Many people have lost their possessions, their homes, and even their lives in some cases, as a direct result of coal fires. The toxic and carcinogenic gases released from coal fires have had a negative effect on the flora and fauna in the area of the fire. Vast areas of forest have been killed simply from the immense amount of underground 
heat generated by smoldering fires. Furthermore, the amount of gasses that spew into the atmosphere have been documented to travel great distances and effect people, plants and animals far away from the source of the fire.

All these ideas are important to the student of science. I believed that the students I was teaching needed to be better equipped to make informed and educated decisions in the future. Having a solid understanding of the impact of coal fires should help scienceeducated students extrapolate their knowledge into greater areas of science including environmental science, the health and wellness sciences, and physical sciences such as chemistry and geology. To fully understand the source of coal fires, their life cycle, and their eventual environmental impact, a student must be proficient in all of these areas of science.

Being scientifically educated has a great benefit. However, being personally equipped to make environmentally responsible decisions is at least as important, if not more so. As my students grow and are faced with daily decisions related to their environment and the world around them, I hope that what they have gained from lessons such as this will help guide them to make proper decisions for the environment that will positively impact and preserve our world. 


\section{Chapter 3 - Unit Design}

\section{School/Student Background}

The geographic area that I worked in was a relatively wealthy community; however many students were still from lower socio-economic status and a noteworthy percentage (20-25\%) of the student population received free/reduced lunch in any given year. In the classes where I presented the coal fire lessons there was a wide range of academic abilities and diverse socioeconomic backgrounds. Earth Science at Russell was considered a $9^{\text {th }}$ grade level class; however a few sophomores and one junior were scattered throughout the four sections that I taught.

\section{Review of Standards}

The objectives that applied to this lesson were taken from the Kentucky Core Content for Science Assessment 4.1, last revision August 2006. Kentucky was in the midst of a grand re-vamping of all their curriculum standards. Many of the core content areas had already been revised or were in the process of being revised. Teachers throughout the state were diligently working to realign their curriculum and assessments to coincide with the Common Core Standards that have been adopted by almost every state in the Union. According to the www.corestandards.org website, only a very few states have not adopted Common Core as the new educational standard for their State.

Kentucky had adopted Common Core with a slight stipulation. Kentucky left a small widow of adaptability, allowing approximately $15 \%$ of most standards to either be added to or not fully accepted as schools implemented new educational benchmarks throughout the State. 
Kentucky was only about half complete in adapting and revising Common Core

for the science classroom. Therefore, all teachers were required to continue teaching the standards found in Kentucky Core Content for Assessment 4.1. All the standards that I used matched CCA (Core Content for Assessment) for the Coal Fire lessons.

The content standards that were addressed in the Coal Fire lessons were:

\section{SC-HS-2.3.6}

Students will:

- compare the limitations/benefits of various techniques (radioactive dating, observing rock sequences and comparing fossils) for estimating geological time;

- justify deductions about age of geologic features.

Techniques used to estimate geological time include using radioactive dating, observing rock sequences and comparing fossils to correlate the rock sequences at various locations.

\section{SC-HS-4.6.4}

Students will:

- describe the components and reservoirs involved in biogeochemical cycles (water, nitrogen, carbon dioxide and oxygen);

- explain the movement of matter and energy in biogeochemical cycles and related phenomena.

The total energy of the universe is constant. Energy can change forms and/or be transferred in many ways, but it can neither be created nor destroyed. Movement of matter between reservoirs is driven by Earth's internal and external sources of energy. These movements are often accompanied by a change in physical and chemical properties of the matter. Carbon, for example, occurs in carbonate rocks such as limestone, in the atmosphere as carbon dioxide gas, in water as dissolved carbon dioxide and in all organisms as complex molecules that control the chemistry of life.

The Standards found in the CCA were very generalized. Adaption of the use of energy from natural resources was to be gleaned from the above standards. The lessons presented here will support that end.

This study and research aimed to answer questions pertaining to the effect of Kentucky's coal fires on the environment and the possible adverse health effects on people. At the time of this research, numerous pollutants that exceeded safe limits were 
pouring out of multiple coal fires, or being produced by coal related industry, and my research attempted to ascertain the type and extent of the effects of pollutants on the ecosystem and nearby inhabitants.

All high school students in Kentucky schools are required to create a portfolio piece that demonstrated their ability to compose a scientific document, a requirement that fulfilled State of Kentucky education standards. Examples of documents meeting the criteria included a laboratory report or a scientific literary review. For the purpose of the Coal Fire unit, I chose to have students review scientific literature related to coal production in Kentucky and coal fires. Generally speaking, in my experience as a high school science teacher, I found that many students seemed to be lacking true science literacy. By that I mean students didn't seem to know how to appropriately support ideas and theories with scientifically sound reasoning. The Coal Fire lessons and reports provided a timely opportunity for students to practice writing a scientific research paper while utilizing teacher and peer review.

\section{Commencing the Unit Study}

I planned to introduce this topic of coal fires with research and literature on the subject of coal fires. Morehead State University (MSU) was located just a few miles away. MSU researched and documented environmental issues related to the mining industry such as coal fires, ash ponds, and the effects of coal dust. I utilized information gathered from MSU's research studies to introduce the subject of coal fires to my classes. We had made a habit throughout the school year of reading and reflecting on scientific articles. Therefore, it was a smooth transition for students to read the reports from Morehead State and begin their own articles. 
The science department at Russell High School featured a fully equipped computer lab for doing scientific research. My classes spent a day in the computer lab doing online research for their final report/presentation. Students researched various aspects of coal mining, with particular emphasis on coal fires. Data the students gathered was incorporated in their final project.

I had initially considered taking my classes to visit the site of a coal fire. However, after investigating, I was informed by a professor at Morehead that a field trip would not be possible. The amount of toxic gases and carcinogens that come from the coal fires were well beyond acceptable limits for human exposure. Furthermore there would be no way to have access to enough respirators for all students. She did, however, point me in the right direction to be able to watch an informative video that allowed students to view the destructive nature of coal fires.

The final summation of the students' research and experience was presented in a report stating the facts that each student discovered and ideas concerning better or more efficient mining practices. Possible report ideas included new techniques to aid in the effort to extinguish coal fires or improved theories of how to prevent them. As an alternative to a standard research report, I allowed students to write a paper from the perspective of someone who was directly affected by the coal fires or other environmental impacts of the mining industry. The report need not only be limited to human perspective; perhaps there was a specific animal or plant species that was directly affected by these processes and students were given the opportunity to write a paper that cited sources to support the impact on the species and what the species must do to survive. Allowing students to create the aforementioned type of report provided a very 
creative way for students to present their findings and make the assignment a bit more personal. My hope was to make the unit informational and interesting to students of all learning styles.

\section{Narrative Summary of Lessons}

The actual Unit Plan that I used can be found in the Appendix. For the purposes of this chapter, I will provide a narrative summary of the activities. The overall purpose of the Coal Fire unit was to increase student knowledge of coal and coal mining processes with specific emphasis on coal seam fires, coal fire emissions, and the impact of coal emissions on the environment and human health. The student learning objectives to be met by the end of the unit are:

1) create a diagram that showed the coal formation cycle

2) compare and contrast the current process of coal mining with the method of coal mining at the turn of the century

3) organize a chart, graph, or table showing the toxic or hazardous products of combustion from coal fires and their effects on the human body

4) summarize the processes that were currently employed to extinguish coal fires

5) evaluate the efficacy of these processes by examining two agencies which are actively involved in controlling and/or extinguishing coal fires

Day One was designed to be an introduction to the topic of coal with information regarding coal's utilization in residential settings as well as commercial settings. I felt it was important, especially in Appalachia, for students to know how and where coal is mined. Also, many of my students' relatives were coal miners. However, in this particular school, there were also several students who were not born and raised in 
Appalachia, so it was good for them to learn about this very important local industry. As an introductory way of exposing the students to the coal mining industry and some of the hazards involved, students watched segments of two episodes of a documentary of modern day coal mining called "COAL". There was a follow-along video worksheet to use during the video (see Appendix Coal: Documentary of Appalachia's Coal Miners) For homework, students were given an article to read, so they would be ready to engage in the classroom activity related to article reviews.

The second day of the study, information pertaining to coal fires was introduced through literature and documents. Students were split into groups and given copies of different research and documentation concerning coal and coal fires in Kentucky and surrounding states. Each group was assigned different articles. Each group then took turns sharing the information with the class as an introduction to coal and the topic of coal fires. Students shared information about their articles in a "round-robin" fact share method. Furthermore, each group was responsible for creating a typed summary of their article as part of the final assessment process. The written summaries were one- or twopage documents that included a diagram or chart delineating the effects that the products of coal combustion have on the human body. To assist the students in completing the assignment, I provided an "Article Review Template" (see Appendix) to help guide the students in their learning from the coal fire articles.

Class period three was designed for coal fire research on the Internet. For this activity students were given the document "Coal and Coal Fire Internet Investigation" (see Appendix). They had the entire class period in the computer lab to research coal and find the answers to each question on this handout. Furthermore, students were allowed to 
research a topic or idea that caught their interest from the sharing time the previous day. They were able to print or write down ideas and websites for future research and writing. The final project of this unit was a research paper compiled by either a student alone or by a pair of students that were given specific research topics related to their report. This portion of the lesson is where they gained the resources to write and compile their papers outside of class time.

Class period four was designed as a time to review concepts related to coal formation. Students native to Russell Independent Schools had already experienced some exposure to information about coal formation in previous middle school classes, so this was a review for most students rather than an introduction. Class notes were given regarding coal formation. Technology that was utilized for this lesson included overhead notes shared using a document camera as well as information that was viewed by students using the classroom computer.

Class period five was designed to show students footage of actual coal fires. We also focused on the environmental and human impact caused by coal fires. My original plan had been to watch portions of two National Geographic videos, "Built For Destruction: Wildfires" and "Underground Inferno." However, after extensive trying on my part including contacting universities with coal studies programs and contacting National Geographic directly, I was unable to obtain access to either video. However, I was able to locate several video clips on You Tube that were informative, and we had extended class discussions about the fires, their formation, and the impact on the environment. We also discussed current methods that were being used to manage and extinguish coal fires, and the effectiveness of each. 
Class period six was designated as a review day. Students reviewed in class the information that they had learned throughout the Coal Fire unit and prepared for a short assessment the following day covering coal fires, emission gasses, and their effect on the environment and human health.

Class period 7 was the final day of the Coal Fire unit. The assessment during class consisted of ten multiple-choice questions and four short answer/open response questions. The quiz accounted for half of the points awarded for the coal fire unit. The other half of the assessment points came from the report that was assigned at the beginning of this unit, which were due right before the quiz.

Below is a table summarizing the daily lessons. (Table 1)

Table 1. Summary of Daily Lessons

\begin{tabular}{|c|c|c|}
\hline $\begin{array}{l}\text { Day of } \\
\text { Lesson }\end{array}$ & Activity in class & Work expected outside of class \\
\hline Day 1 & $\begin{array}{l}\text { COAL documentary with } \\
\text { follow-along video notes }\end{array}$ & $\begin{array}{l}\text { Coal article to read and be ready } \\
\text { to discuss }\end{array}$ \\
\hline Day 2 & $\begin{array}{l}\text { Read Coal articles in class - } \\
\text { "round robin" sharing }\end{array}$ & $\begin{array}{l}\text { Begin article summary due next } \\
\text { week }\end{array}$ \\
\hline Day 3 & $\begin{array}{l}\text { Coal and Coal Fire Internet } \\
\text { Investigation done in class }\end{array}$ & $\begin{array}{l}\text { Complete Internet Investigation } \\
\text { (if not completed) and work on } \\
\text { article summary }\end{array}$ \\
\hline Day 4 & $\begin{array}{l}\text { Class notes and classroom } \\
\text { instruction regarding coal } \\
\text { formation and mining practices }\end{array}$ & Continue article summary \\
\hline Day 5 & $\begin{array}{l}\text { Video footage and class } \\
\text { discussion of current and past } \\
\text { coal fires and extinguishment }\end{array}$ & $\begin{array}{l}\text { Review coal information to } \\
\text { study for unit assessment; } \\
\text { continue article summary }\end{array}$ \\
\hline Day 6 & $\begin{array}{l}\text { Review all concepts in class for } \\
\text { summative assessment review }\end{array}$ & $\begin{array}{l}\text { Study unit information to be } \\
\text { ready for summative } \\
\text { assessment; complete article } \\
\text { summary }\end{array}$ \\
\hline Day 7 & $\begin{array}{l}\text { Summative assessment in class; } \\
\text { article summaries due to } \\
\text { instructor }\end{array}$ & none \\
\hline
\end{tabular}




\section{Chapter 4 - Presentation and Interpretation of Data}

\section{Pre-Test and Post-Test Comparison}

This study focused on using the coal production processes and subsequent activities and a tool to aid in high school students learning more about being informed and involved environmental citizens. At the time of my research, there were several different methods of coal mining in operation, from mountain top mining to deep underground mining, and each presented it's own set of hazards to the environment. One of the hazards that were common to almost all methods of coal mining was the potential for a coal seam fire.

To test for prior knowledge of mining practices and other coal-related concepts, I gave each student a pre-test consisting of ten multiple choice questions. The pre-test can be found in the appendix entitled "Coal Pre-Test." Throughout the Coal Fire unit, other avenues of learning were covered also, including Internet research, video instruction with video notes, and a research paper covering a topic of the students' choice. Finally, the End of Unit Assessment was given as a final evaluation when the unit was completed. (Table 2)

Table 2. Target Concepts and Test Questions ${ }^{1}$

\footnotetext{
${ }^{1}$ A percentage of correct answers are shown from the pre-test and also from the post-test as evidence of authentic understanding. Also, certain open response answers from actual student tests have been chosen to demonstrate how some concepts were understood correctly, and also some to demonstrate how students had certain misconceptions.
} 


\begin{tabular}{|l|c|c|}
\hline \multicolumn{1}{|c|}{ Target Concept } & $\begin{array}{c}\text { Pre-Test Question that } \\
\text { Addresses the Objective }\end{array}$ & $\begin{array}{c}\text { Post-Test Question that } \\
\text { Addresses the Objective }\end{array}$ \\
\hline $\begin{array}{l}\text { History of coal mining in } \\
\text { the Appalachian area }\end{array}$ & Numbers & Numbers 6,7 \\
\hline Types of coal mines & Numbers1, 5, 8, 10 & Numbers \\
\hline Causes of coal fires & Number 2 & Numbers 2, 4, 8, 11 \\
\hline $\begin{array}{l}\text { Information about specific } \\
\text { fires }\end{array}$ & Numbers & Numbers 3,5 \\
\hline $\begin{array}{l}\text { Environmental impact of } \\
\text { coal fires }\end{array}$ & Numbers 3, 4, 6,11 & Numbers 1,11,13 \\
\hline $\begin{array}{l}\text { Human health impact of } \\
\text { coal fires }\end{array}$ & Numbers & Numbers 10,12,13 \\
\hline Extinguishing coal fires. & Numbers & Numbers 9, 10,13,14 \\
\hline $\begin{array}{l}\text { Questions in test not } \\
\text { addressing learning } \\
\text { objectives }\end{array}$ & Numbers 7, 9 & None \\
\hline
\end{tabular}

\section{Pre-Test (Formative Assessment) Analysis}

Initially, I had planned to spend time on concept \#1-History of Mining in the Appalachian Area and concept \#2- Types of Coal Mines, as individual concepts.

However, I have chosen to lump these two topics together because they became so closely related during my lessons. I initially thought that there would be much more time spent covering the differing types of coalmines and also a lot of history related to mining in the Appalachian Mountains, of which Russell, KY, is a part. However, as the lesson progressed, I found that much more time was spent learning about coal fires and their impact. However, even with that instructional shift, there was still a good amount of learning related to history and specific types of mines in the Appalachian area.

I was surprised to find that, upon closer analysis, my Pre-Test did not cover as much of the coal fire causes and health impact as I had originally intended. However, there were other parts of the lessons that certainly incorporated those concepts. 
Table 3. Coal Pre-Test Question Analysis 1

\begin{tabular}{|c|c|c|c|}
\hline \multicolumn{4}{|c|}{$\begin{array}{l}\text { Coal Pre-Test } \\
\text { Percentage of student's correct } \\
\text { answers }\end{array}$} \\
\hline Test Question \# & $\begin{array}{c}\text { \# of Correct } \\
\text { Answers }\end{array}$ & $\frac{\text { Total \# of }}{\text { Tests Given }}$ & \% Correct \\
\hline 1 & 45 & 59 & $76 \%$ \\
\hline 2 & 37 & 59 & $63 \%$ \\
\hline 3 & 14 & 59 & $24 \%$ \\
\hline 5 & 35 & 59 & $59 \%$ \\
\hline 7 & 31 & 59 & $53 \%$ \\
\hline 8 & 32 & 59 & $54 \%$ \\
\hline 9 & 16 & 59 & $27 \%$ \\
\hline 10 & 15 & 59 & $25 \%$ \\
\hline
\end{tabular}

It can be derived from the above data that there was a varying amount of understanding demonstrated in the Pre-Test. Question \#1 was specifically related to mining and mining processes and $76 \%$ of the students knew about this. Even if each student was not confident in the answer that he chose, it would make sense that most students in this area of the United States would be familiar with some of the terminology related to mining processes. It is fairly common in everyday talk around our area.

Questions \#2, 3, 5, 7, 10 focused on coal as a fossil fuel. I had expected that most students would be somewhat familiar with the term fossil fuel and the very basics of how fossil fuels are formed. Most students begin to learn about environmental issues in primary school, and although these questions did not exactly describe environmental issues as much as some of the other questions did, students still must learn about fossil fuels when they discuss the environment in elementary science classes. 
With correctness percentages of $63 \%, 24 \%, 59 \%, 53 \%$, and $25 \%$, I was again surprised that more students were not aware of how coal is formed (questions \#5 and \#7). Coal formation is a basic concept that I assumed most students would know by $9^{\text {th }}$ grade. The low percentage on question \#10 did not surprise me, however, because the correct answer was the term "lode," which is not a commonly used term other than by people directly associated with the mining industry. Other questions on the Pre-Test focused more on the environmental impact of the coal industry. There are several ways that coal mining effects the environment. Two of those methods are addressed in question \#4 addressed damage to the ecosystem as a result of coal mining, and question \#6 inquired about sulfur dioxide being released during the burning of coal. (Table 4).

Table 4. Environmental Questions Pre-Test Analysis 2

\section{Coal Pre-Test}

\section{Percentage of student's correct}

\section{answers}

\begin{tabular}{cccc}
\hline Test Question \# & $\begin{array}{c}\text { \# of Correct } \\
\text { Answers }\end{array}$ & $\begin{array}{c}\text { Total \# of } \\
\text { Tests Given }\end{array}$ & \% Correct \\
\hline $\mathbf{4}$ & 35 & 59 & $59 \%$ \\
$\mathbf{6}$ & 31 & 59 & $53 \%$ \\
\hline
\end{tabular}

I was surprised that students scored in the $50 \%$ range on these questions than for some of the other questions. Since this is a pre-test and, as such, I did not cover any of these topics before the test was given, I expected that most students would not know very much about reclamation or about sulfur dioxide. I suspected that hardly any students would know about sulfur dioxide nor what reclamation is related to coal mining. It may be possible that students simply picked the answer to the questions that they are most familiar with or that many guessed randomly. 
Lastly, the Pre-Test also included an open response question, which I felt would be a good method for students to share previous understanding regarding impact of the mining industry. The question was, "Why must the mining industry be concerned with the Endangered Species Act?" The answers given showed that many students had a grasp of this concept. However, other answers demonstrated that some students had no idea how to formulate an answer. It is possible that some did not know what the Endangered Species Act was; however, I had hoped that, even if a student didn't know what this Act was specifically, he or she would be able to use the context of the question to formulate a reasonable answer. Some answers showed this, but others did not.

Here are examples of answers given that demonstrated understanding of the concept.

1) So they won't kill the endangered species

2) Because they destroy the ecosystems

3) Stuff they mine can send out gasses that can kill them

4) When they do surface or strip mining it destroys the ecosystem

5) They could destroy animal habitats and ecosystems

The following are answers that showed little or no understanding of the entire context of the question:

1) For electric power

2) The people will be mad

3) Because of the evil PETA

4) Because they need more dead animals for fossil fuels 
And, sadly, there were 20 questions left blank. I have found over my years of teaching that students do not try to answer as many open response questions if it is not for credit. These students knew that the pre-test was not for credit, so I suspect that is why such a large percentage (34\%) of the open response questions were left blank.

\section{Ongoing Formative Assessment}

Learning occurred through a variety of mediums during the Coal Fire unit. As an introductory activity, students were given a choice of four printed articles from which they were each expected to take the two that interested them the most. They were instructed to read those two articles and fill out an Article Review Template (see Appendix) for each article. The articles were specifically chosen so that students would be exposed to specific details concerning coal fires and their impact on humans and also on the environment. By choosing any two of the four articles, students would read about specific coal fires that caused special impact to people, specifically the fire in Centralia, PA, where virtually all the residents of that city were required to relocate because of the health hazards surrounding the area of the fire. Other articles of the four options also described some of the environmental impacts such as the deforestation surrounding coal seam fires in Pike County, KY.

Offering four articles and requiring students to read them guided student learning more directly than the individual Internet research portion of the Coal Fire unit. Internet research, as previously discussed, was a good way for students to take more ownership of their learning and be more independently self-guided. However, as there were specific concepts that I felt needed to be emphasized, I carefully chose and offered to the students 
four articles that I thought were informative, instructional, and at a more reasonable readability level than some of the articles I utilized during my research.

As students read the articles and filled out the Article Review Template, we had class discussions where students shared their learning in a "round robin" sort of way. Students raised their hands if they had chosen a certain article. The teacher called on one student at a time and asked the student to give one idea regarding the article's content or importance. Then the next student gave one more idea or concept from the same article. We continued in that fashion until five or six student responses had been given. I then finished up with an overall summary of the article before the class moved on to the next article, reviewing and discussing the same way.

In my experience, generally only a few students would voluntarily engage in a class discussion activity. However, I required the reading to be done in class, so I knew that all the students were actively engaged. I found assigning the reading in class rather than as a homework assignment was a very appropriate method, as student participation was surprisingly active. As a rule, I have found that students usually don't mind answering questions as long as they are confident in two things: 1- they feel that they have a suitable answer, and 2- they feel safe in the classroom, meaning, they feel that they can share an answer and, if it happens to be wrong, they will not be teased or ridiculed because of it. By spending class time allowing students to read the articles, they knew that they had a decent level of understanding of the articles, which seemed to be enough to encourage them to answer questions in class. During the "round-robin" activity, I usually had 8 or 10 students willing to share their answers. Often, they would 
"piggy-back" answers from other students, adding thoughts that piqued their interest or their knowledge of the articles.

Later in the unit, the students spent considerable time outside of class learning more about the coal industry by completing a research paper. It is interesting to note that some valuable learning took place through students' time researching. It is always important for educators to remember that learning is not like a "stop-and-go" light. Rather, learning is more like a highway, where sometimes there are great gains in learning and sometimes there is only a little learning. However, learning is more of a continuous journey rather than ever coming to a long arduous stop.

The subject matter in these research papers was intended to meet the learning objectives \#3-7 as listed above. Not every paper was intended to completely incorporate every learning goal; however, to a varying degree, each paper at least touched on several of these goals.

For the article summary, each student was allowed to choose their own topic of study as long as it was related to coal mining/coal fires and their hazards, as shown in the Article Summary Directions document in the Appendix. I felt it would be beneficial to share some of the thoughts that were brought out in the research of various students. The following are a few quotes as examples of quality learning through research. Any grammatical errors have been corrected where they would not change the intended meaning or continuity of the author's intent.

"From the research I have done, I have learned that there are an estimate of about thirty coal mining deaths per year in the United States. However, in less developed countries, there can be more than six thousand deaths per year." This student 
demonstrated that he was aware of events outside the United States, knowledge that he did not gain during classroom instruction, so it was evident that he had taken his independent research seriously.

Another student wrote, "No matter what all mining is bad for the environment because any kind of mining has to let off methane gasses." This student learned that the process of mining releases methane which can be damaging to the environment. The student did not demonstrate knowledge of the fact that many other natural and synthetic processes also release methane gas into the environment. All that being said, there is certainly authentic learning demonstrated.

As a final example, "It's hard to believe but other countries have a lot worse coal seam fires than the United States does. In areas around the burning Chinese Wuda Coalfield and the Liuhuanggou coal fire, the smoke was so thick that you can't even see 20 feet in front of you, or in any direction around you. When there is a coal fire such as these, the gasses are carried by the wind, being sent into other cities, also." This student demonstrated a good extension of knowledge as well as showing the ability to extrapolate information.

\section{Post-Test Analysis (Summative Assessment)}

The Coal and Coal Fires End of Unit Assessment (see Appendix) was the culminating event for my lesson plan. Each question addressed learning goals just as the Coal Pre-Test did. Below is a synthesis of each question and the data supporting the learning that occurred during the Coal Fire unit lessons. The exam consisted of a multiple-choice section as well as short answer open response questions. 
Multiple choice answer analysis.

Question \#1: One of the common complaints concerning coal is that when it is burned for energy it emits many undesirable products into the air. Which of the following is a process used to lessen the amount of undesirable products? (correct answers are in italics)

a) synthetically creating a coal substitute.

b) washing and drying coal before burning

c) mining coal with cleaner equipment

d) finding coal seams in cleaner areas of the world

Table 5. Summary of Post-Test Multiple Choice Question 1

\section{Coal Post-Test \\ Percentage of student's \\ correct answers}

\begin{tabular}{|c|c|c|c|}
\hline Test Question \# & $\frac{\# \text { of Correct }}{\text { Answers }}$ & $\begin{array}{c}\text { Total \# of } \\
\text { Tests Given }\end{array}$ & \% Correct \\
\hline 1 & 19 & 67 & $28 \%$ \\
\hline
\end{tabular}

This question addressed learning the learning objective Environmental Impact of Coal

Fires. Throughout the lesson, there was a lot of time spent learning about coal fires and their impact on the environment. However, the low percentage of correct responses indicates a lack of learning concerning one specific portion of lessening environmental impact, that being what do coal companies do to help lower impact in the areas where they operate. At the time of research, one very specific operation that many coal companies did was to wash the coal and dry it before it was burned in power plants or other production facilities. This point was covered in some of the reading materials that students were exposed to, but it was not openly discussed in class very often. I am not 
surprised that only $28 \%$ of test takers got this correct. If it is assumed that all students guessed on this question, there would be about a $25 \%$ chance of getting it correct, so are no better than if students did not understand the question at all.

Question \#2: The underground smoldering of a coal vein or coal deposit is properly referred to as (a)
a) coal smolder
b) coal bed fire
c) coal seam fire
d) coal smoke

This question addressed learning the learning objective Causes of Coal Fires.

Table 6. Summary of Post-Test Multiple Choice Question 2

\section{Coal Post-Test \\ Percentage of student's \\ correct answers}

\begin{tabular}{cccc}
\hline Test Question \# & $\begin{array}{c}\text { \# of Correct } \\
\text { Answers }\end{array}$ & $\begin{array}{c}\text { Total \# of } \\
\text { Tests Given }\end{array}$ & \% Correct \\
\hline 2 & 54 & 67 & $81 \%$ \\
\hline
\end{tabular}

This is another important subject related to what students were expected to learn, but in this case I expected virtually every student to answer this question correctly. This is a definition question. The fact that only $81 \%$ of students answered the question correctly may indicate the possibility that students were not paying attention during class, or that perhaps a handful of students did not understand the question or simply randomly guessed at the answers to the multiple choice questions. 
Question \#3: Coal fires are a problem

a) throughout the world

b) only in America

c) only in Europe

d) only in mountainous regions

This question addressed learning the learning objective Information about Specific Fires.

Table 7. Summary of Post-Test Multiple Choice Question 3

\section{Coal Post-Test}

\section{Percentage of student's}

\section{correct answers}

\begin{tabular}{cccc}
\hline Test Question \# & $\begin{array}{ccc}\text { \# of Correct } \\
\text { Answers }\end{array}$ & $\begin{array}{c}\text { Total \# of } \\
\text { Tests Given }\end{array}$ & \% Correct \\
\hline 3 & 67 & 67 & $100 \%$ \\
\hline
\end{tabular}

All students answered this question correctly. I had wondered if anyone would happen to answer D (only in mountainous regions) based on the idea that we live in a mountainous region that has coal fires, but no one did.

Question \#4

TRUE or FALSE: It is possible for coal to spontaneously combust.

This question addressed learning the learning objective Causes of Coal Fires.

Table 8. Summary of Post-Test Multiple Choice Question 4

\section{Coal Post-Test}

\section{Percentage of student's}

correct answers

\begin{tabular}{|c|c|c|c|}
\hline Test Question \# & $\frac{\text { \# of Correct }}{\text { Answers }}$ & $\frac{\text { Total \# of }}{\text { Tests Given }}$ & \% Correct \\
\hline
\end{tabular}




\begin{tabular}{llll}
\hline 4 & 66 & 67 & $99 \%$ \\
\hline
\end{tabular}

Question \#4 was a true/false question. I realize that many educators do not approve of these types of questions because it does not lead to a positive identification of acquired knowledge in the student. And to a certain degree, I agree with them, as it is often too easy for a student to look at a true/false question and simply guess, realizing that they have a 50/50 chance at getting it right. However, I believe that there are times when a true/false question is acceptable.

While teaching this lesson, we learned that one common cause coal seam fires is spontaneous combustion. This fact alone was quite amazing to most of my students. For one thing, the term "spontaneous combustion" was very common among high school students. They often looked for things in science to be "big" and "explosive" and "fascinating". So, when they learned that coal could "spontaneously combust," they were interested. And I believe the results speak for themselves.

I don't know exactly what happened regarding the one person who got this question wrong. Many students are more inquisitive than they even like to admit; they very often look for trick questions. I suppose it is possible that this person assumed the question was a trick question, or they simply didn't know the answer.

Question \#5: The oldest recorded coal fire on record, which is in New South Wales, Australia, has been burning for more than years.
a) 2
b) 20 
c) 200

d) 2,000

This question addressed learning the learning objective Information about Specific Fires. Table 9. Summary of Post-Test Multiple Choice Question 5

\section{Coal Post-Test \\ Percentage of student's \\ correct answers}

\begin{tabular}{cccc}
\hline Test Question \# & $\begin{array}{c}\text { \# of Correct } \\
\text { Answers }\end{array}$ & $\begin{array}{c}\text { Total \# of } \\
\text { Tests Given }\end{array}$ & \% Correct \\
$\mathbf{5}$ & 60 & 67 & $90 \%$ \\
\hline
\end{tabular}

One of the learning objectives throughout this lesson was that most coal fires found around the world were initially ignited by means other than human involvement. More specifically, I hoped students would learn that, although mankind has certainly made mistakes that have caused some dramatic coal fires, most coal fires are outside the [cause] of human involvement.

One way of providing substantial evidence for student learning in this case was to show that there were coal fires that had been burning since before man had machinery. Machinery and poor mining practices were normally how mankind could be blamed for our portion of coal seam fires. But long before there were machines and large scale mining, coal fires still existed, as proved by the existence of the coal fire in New South Wales, Australia. No one knows the cause of this fire, but there was evidence that it had been burning for 2000 years or more, long before poor mining practices and misuse of machinery could be to blame. I hoped that by giving my students an opportunity to make connections between the modern age and times so long ago, it would be easier for them to remember facts about significant events. 
Questions \#6: The leading country of the world in coal production is
a) Russia
b) China
c) The United States
d) Mexico

Question \#7: The leading country of the world in coal reserves is
a) Russia
b) China
c) The United States
d) Mexico

These questions addressed learning the learning objectives History of Coal Mining in the Appalachian Area and Information about Specific Fires.

Table 10. Summary of Post-Test Multiple Choice Questions 6-7

\section{Coal Post-Test}

\section{Percentage of student's} correct answers

\begin{tabular}{cccc}
\hline Test Question \# & $\begin{array}{c}\text { \# of Correct } \\
\text { Answers }\end{array}$ & $\begin{array}{c}\text { Total \# of } \\
\text { Tests Given }\end{array}$ & \% Correct \\
\hline $\mathbf{6}$ & 57 & 67 & $85 \%$ \\
7 & 54 & 67 & $81 \%$ \\
\hline
\end{tabular}

I have addressed these two questions in the same response because they are directly related to each other. I wanted the students to learn about coal mining throughout the 
world so that they would get an idea related to the rich coal mining history found here in Appalachia. The United States, for many years, has romanticized the profession of coal mining. We have made movies, written songs, printed books, and created tourist attractions where one can tour old coalmines to learn about how hard the lifestyle was.

Because of that, I wondered if students may have had the impression that coal mining and the lifestyle that goes with it was exclusive to the United States, or perhaps only in Appalachia. I felt it was important for students to know that coal mining was a worldwide endeavor, and had been for years. Furthermore, I wanted them to realize that there are other countries that have more coal and also mine more coal than the United States. At the time of research, Russia had more coal than any other country of the world. Interestingly, China had less coal than Russia, but still produced (mined and used) more coal than any other country. The United States also produced more coal than Russia, even though Russia had the most in reserve. From the percentage of correct answers for these questions, I believe that the students gained a good understanding that coal production was very common worldwide.

Question \#8: Most of the coal fires burning today are the result of
a) spontaneous combustion
b) natural occurrences (i.e. lightning)
c) human activity
d) all three processes

This question addressed learning the learning objective Causes of Coal Fires.

Table 11. Summary of Post-Test Multiple Choice Question 8 


\section{Coal Post-Test}

\section{Percentage of student's}

correct answers

\begin{tabular}{cccc}
\hline Test Question \# & $\begin{array}{c}\text { \# of Correct } \\
\text { Answers }\end{array}$ & $\begin{array}{c}\text { Total \# of } \\
\text { Tests Given }\end{array}$ & \% Correct \\
\hline 8 & 45 & 67 & $67 \%$ \\
\hline
\end{tabular}

Throughout the Coal Fire unit, we studied several ways that coal fires start. I wanted the students to understand each of the methods and processes. I found it noteworthy that half (11 of 22) of the students who missed the question put A. spontaneous combustion.

However, I was not actually surprised by that fact since I have found as a teacher that the term "spontaneous combustion" is sort of a buzzword with students. Students are always looking for science to be "dramatic" and "explosive" and I often get asked the question, “Are we going to burn anything today?" Additionally, every year I get asked a series of questions related to spontaneous combustion, from whether or not it is true to the urban legend of human spontaneous combustion. Therefore, the fact that coal can spontaneously combust given the requisite circumstances was one of the most talked about and interesting facts of the unit, and it was not surprising that a number of students chose $\mathrm{A}$ as their answer.

Question \#9: Compared to the heat output of coal, wood is
a) much higher
b) much lower
c) about the same

This question addressed learning the learning objective Extinguishing Coal Fires. 


\section{Coal Post-Test}

\section{Percentage of student's}

correct answers

\begin{tabular}{cccc}
\hline Test Question \# & $\begin{array}{c}\text { \# of Correct } \\
\text { Answers }\end{array}$ & $\begin{array}{c}\text { Total \# of } \\
\text { Tests Given }\end{array}$ & \% Correct \\
\hline 9 & 60 & 67 & $90 \%$ \\
\hline
\end{tabular}

One of the main themes of this unit was the environmental impact of coal fires. If one were trying to lessen the environmental impact of coal fires, one of the most obvious methods would be to extinguish the fire. As we learned in this unit, extinguishing a coal fire is a task easier said than done. The reason is that coal burns so much hotter than wood, or other materials that firefighters are often faced with extinguishing. Firefighters or other coal workers cannot enter a coal mine and spray water on burning coal to extinguish it. That method has been tried many times and has very little effect, not to mention the fact that the amount of steam produced can also burn firefighters.

Students answered this question accurately, which supports the idea that they learned the difference between the thermal output of coal when compared to other materials, in this case wood.

Question \#10

Coal fires emit toxic gasses into the environment, which include
a) carbon monoxide
b) methane
c) mercury
d) all of these

This question addressed learning the learning objectives Environmental Impact of Coal Fires and Human Health Impact of Coal Fires. 


\section{Coal Post-Test}

\section{Percentage of student's}

correct answers

\begin{tabular}{cccc}
\hline Test Question \# & $\begin{array}{c}\text { \# of Correct } \\
\text { Answers }\end{array}$ & $\begin{array}{c}\text { Total \# of } \\
\text { Tests Given }\end{array}$ & \% Correct \\
10 & 58 & 67 & $87 \%$ \\
\hline
\end{tabular}

The central theme of the entire unit was to study the effects that coal fires of Eastern Kentucky have on the environment and on human health. The students learned about some of the toxic gases that are emitted from coal fires, whether emissions originated from coal seam fires or from coal burned in power plants. For my students, (mostly ninthgraders) many of the chemical names and spellings were too ubiquitous to gain a mature understanding of what the chemicals were. Instead they believed that "weird-named" substances are probably poisonous. It was my job as the instructor to point out that, in chemistry, every substance has a "weird name", but not all things are bad for humans or the environment.

In the case of coal fires, however, many of the "weird named" substances definitely have some degree of negative impact on human health and the environment. Students found these during their reading, their Internet research, and also in the classroom discussion. I chose specific substances to name in question 10 that were familiar to the students. I did not expect the students to know everything about these substances, but at least they were terms that students might use in their everyday language, at least in certain situations. It was my hope that when tested about hazardous substances, they could put down an educated answer.

Many students got this question correct. I believe that they had a good grasp on 
the substances that are hazardous. It would have been easy for a student to look at this question and think that carbon dioxide comes from the body so it must not be toxic. But if they learned that an atmosphere that is rich in carbon dioxide is toxic to humans, then they could answer this question correctly. I trust it was this sort of reasoning that allowed the students to do so well on this question.

There were four short-answer open-response questions in the final assessment. Below is an analysis of the answers to those questions with a rubric of how the questions were scored.

(Table 14)

Table 14. Scoring Rubric for 4-point Open Response Question.

\begin{tabular}{|c|l|}
\hline $\begin{array}{c}\text { Points } \\
\text { Earned }\end{array}$ & Criteria \\
\hline 0 & $\begin{array}{l}\text { 0 points means no answer was given } \text { or answer does not make coherent } \\
\text { sense related to the question. }\end{array}$ \\
\hline 1 & $\begin{array}{l}1 \text { point means only part A or part B was answered but not both. The } \\
\text { answer given only named a process/criteria, but gave no explanation. }\end{array}$ \\
\hline 2 & $\begin{array}{l}\text { 2 points means only part A or part B was answered, but not both. The } \\
\text { answer given correctly named the process/criteria and explained the } \\
\text { process/criteria. }\end{array}$ \\
& $\begin{array}{l}2 \text { points means both part A and part B were answered adequately and } \\
\text { succinctly. However, each part only named a process/criteria, but gave no } \\
\text { explanation. }\end{array}$ \\
\hline 3 & $\begin{array}{l}\text { 3 points means both part A and part B had answers given. However, only } \\
\text { one part was answered adequately and succinctly. The other part only } \\
\text { named a process/criteria. }\end{array}$ \\
\hline 4 & $\begin{array}{l}\text { 4 points means both part A and part B were answered adequately and } \\
\text { succinctly. }\end{array}$ \\
\hline
\end{tabular}

Question \#11: Describe two methods of how coal fires get started. 
This question addressed learning the learning objective Causes of Coal Fires.

(Graph 1)

Graph 1: Percentage of Points Earned: Question 11

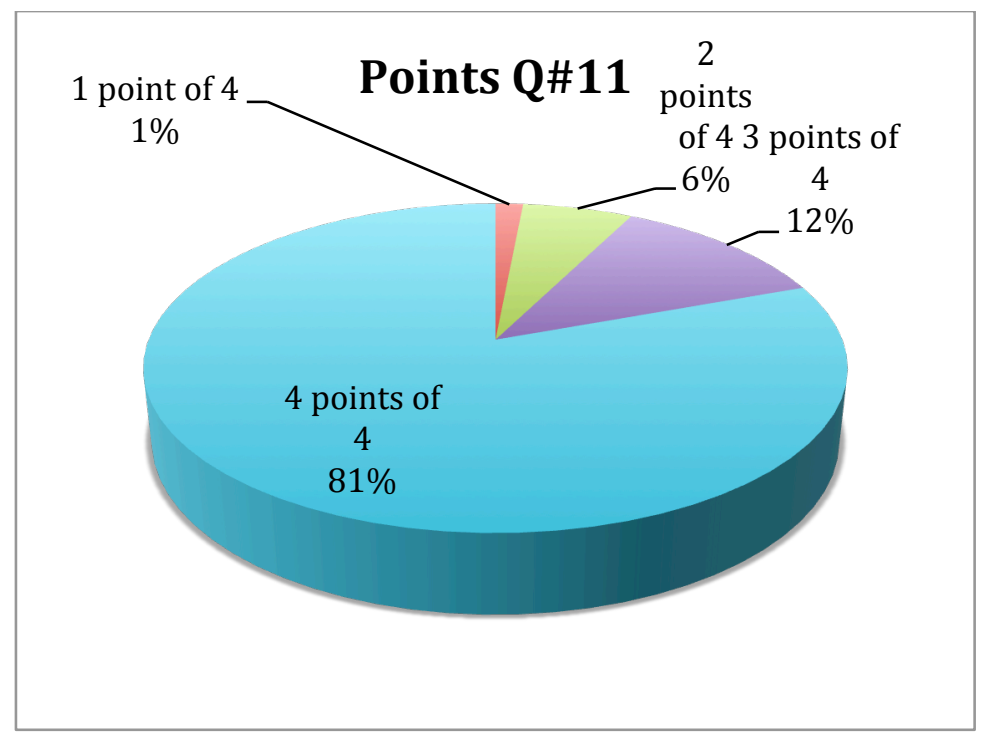

This question was a very well answered question by the class as a whole. There was no test that left this entire question blank. I was very happy to see that. Often students leave questions blank if they don't think they can score very highly on the question.

The student answer for the only 1-point test question was "natural occurrences like lightning." This is a correct answer, but apparently the student could not think of another answer to list. However, on the same page of this test is question \#8. This is the multiple-choice question that gives options of which ways coal fires get started. A teacher would likely expect that this student would have answered the multiple choice question the same way that she answered this open response question, but she didn't. She answered "all three processes equally combined" for question \#8. So, why didn't she think to look back in her test and use the previous multiple-choice question to help her 
with the open response question? I always find it difficult to teach students to use the test while taking the test. This student had not learned this key test-taking skill yet.

The students offering answers that earned two points all simply listed two methods of how coal fires get started, except for one student. Her answer was:

A) People drop different gasses underground while mining that can set off fires.

B) The mine can cave in and collapse and hit the different wires.

She earned 2/4 points for this answer based on her answer for part B only. Part A was nonsensical and therefore earned 0/4 points. But part B gave, at least, a possible scenario of how a coal seam fire might start along with an explanation.

Answers that earned 3/4 points were graded as the rubric indicates. Either part A or part B had a complete answer, and the other portion only listed a method of ignition, but no description, as the question required.

The following is an example of an answer that earned a complete $4 / 4$ points.

A) Spontaneous combustion - when a piece of coal is heated to $150^{\circ} \mathrm{C}$ or higher, without the help of humans or the environment.

B) Human - people may cause coal fires by burning trash in campfires, etc.

This test response was a good example of following directions and writing complete answers. He described both answers completely. The wording was to the point and accurate.

Question \#12: Name and explain two hazards to humans caused by coal fires. 
This question addressed learning the learning objective Human Health Impact of Coal Fires.

(Graph 2)

Graph 2: Percentage of Points Earned: Question 12

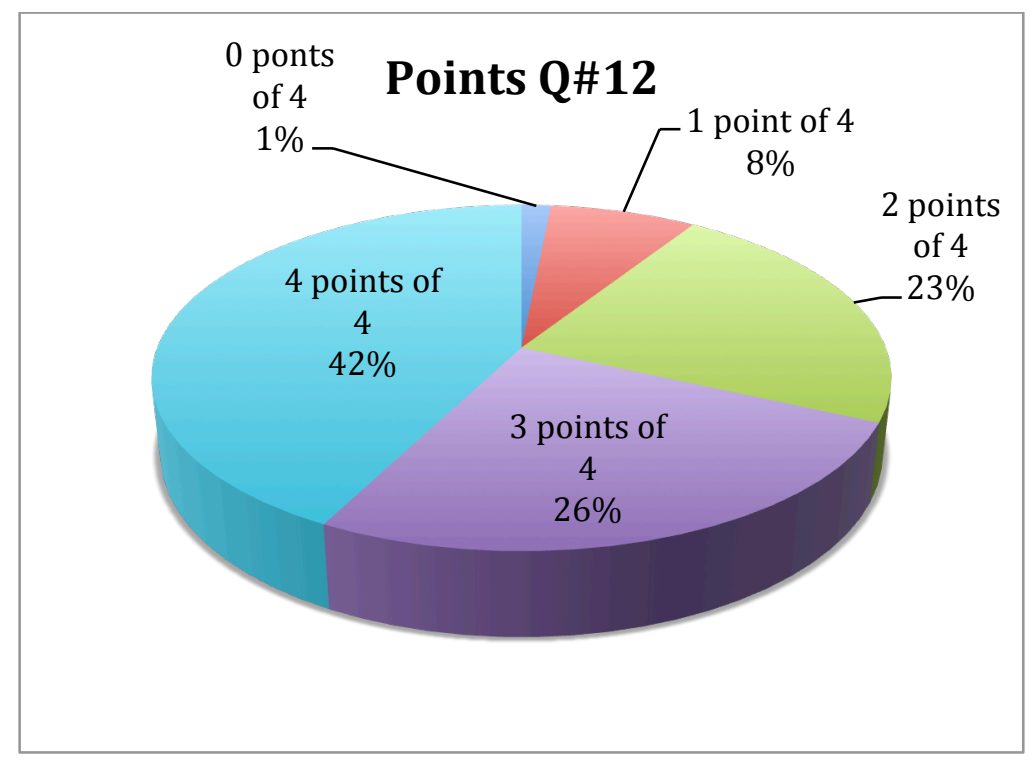

Question 12 turned out to have a more even distribution than the previous question. With only $42 \%$ earning full marks, I initially felt like there should have been more students than this. But, as I looked at the $3 / 4$ points and combined that with the $4 / 4$ points category, I was not all displeased with the student answers. Approaching the analysis that way showed $68 \%$ of the students attained a passing score. That may be a more appropriate way of interpreting the data.

There was, for question 12 , one student who chose to leave the question completely blank, earning a $0 / 4$ point. I have never been able to teach all my students to never leave a question blank. I have tried every year to impress on them that a blank 
answer is a guaranteed failure, and that they should at least attempt an answer. However, there are always those that leave questions completely blank.

Eight percent of the students only earned $1 / 4$ points. This amounted to 5 tests. Generally, as before, the grading ended up being that a student would only name one correct hazard to humans resulting from coal fires. Other answers were often written in conjunction with these correct answers, but did not earn credit. For example,

A) It's a hazard to people's health.

B) It a hazard to the environment and can pollute water and endanger wildlife.

This example only had one fleeting correct answer. The portion that said "can pollute water" was given credit for $1 / 4$ points. I wrote the comment, "How?" on this portion of the answer to try to help the student learn that they must follow through with an explanation. In Russell schools and elsewhere in education at the time of this research, a push in education was to teach students to read open response questions and choose power words, or words that could be used to identify exactly how the question needed to be answered. There were two power words in this open response question and she only seemed to identify one. She was supposed to name and describe. She named one hazard to humans, specifically water pollution. But she failed to identify exactly how that might occur, which of course was the crux of the inquiry.

There were a significantly more answers earning $2 / 4$ points than in the previous question. According to the rubric scoring method, it would seem that if a student figured out the method for answering a 2-part question like \#11, then they should have been able to answer the same way for \#12. However, the data showed that more students missed 
attaining $3 / 4$ on this question than they did for question $\# 11$. Seventeen percent more students earned 2/4 points in question \#11 than they did in \#12.

However, there was an interesting note that went along with this idea. As I looked through this set of tests again, (those who only earned 2/4 points), every single student earned a $3 / 4$ or a $4 / 4$ on question \#11. So, my initial thought was that the students did not follow through with the correct format for answering a 2-part open response question. But that turned out to be untrue. Conversely these particular students knew how to answer this question, as they scored higher on the previous question. So the fault can therefore only lie in the fact that they did not know the content of this question as well as the content of the previous question.

An example of a 2/4 point answer was as follows:

A) Cancer, when burned carcinogens are in the air.

B) Inhale air that can kill you.

This answer earned 2/4 points because each answer is virtually the same. So, it is as if he answered part A correctly and left part B blank.

Another example:

A) Loss of coal; cause loss of non-renewable resources.

B) Toxic gases; toxic gas goes into the air and can cause death.

This answer earned 2/4 because part B was a complete answer, but part A was not related to the question at all.

Before we analyze another question, I think it is important to point out the difference between a 2-point answer 3-point answer. It sometimes seems that when a student writes a 3-point answer, they probably know the fully correct answer, but often 
miss a key point or a key explanation. It is as though the student "almost gets it", but just misses it by a small margin.

Conversely, with an answer that ranks only for 2 points, it appears to be the other way. A student often does not know very much at all of what the correct answer should be, and is grasping at writing an answer that may at least earn 1 point. Sometimes, they get lucky and write one additional thought that bumps them up to a 2-point answer, and they may have not even known that it was an answer that was that valuable.

I point this out because I find it interesting that there seems to be a larger knowledge gap between a 2- and 3- point answer than between the other two margins. It seems as if students are almost split into two categories of open response answers: those whose answers will earn either 1 or 2 points, and those who will earn either 3 or 4 points. It is difficult to see how the spread of answers fall unless a person was to read all the test answers. But I find it a very interesting idea in my educational experience.

Supporting this idea, the following is an example of a 3 point answer:

A) Toxins - toxins put into the air can hurt our health.

B) Damage it does to the environment.

Part B of this answer seemed to be referring to the coal fires as the source of the damage to the environment, and I can read that into the answer. However, that was an example of something that was damaging to the environment, and the question needed an answer to the hazards related to humans.

Another example of how close a 3-point answer can be to a 4-point answer was this:

A) One hazard is the smoke, it is toxic and can cause lung cancer. 
B) Another hazard is that it destroys environments (homes, towns) The first portion of this answer is worth $2 / 2$ points. As I looked at the second portion, initially it would not fit the question because it talks about the environmental hazards. But the student added "(homes, towns)" to the answer, which led me to believe that they viewed a town being destroyed as a hazard to human health. I conceded the point, but could not award full credit because this part did not specifically name the hazard. This is a good example of how close a 3-point answer can be to becoming a 4-point answer in many cases.

Four-point answers are always easy to award credit. They are complete, easy to read, and quickly demonstrate how the student knows what they are talking about.

A) Coal fires put out carbon monoxide and cause pollution.

B) Coal fires put out carcinogens and can poison our bodies.

This was a well-written answer, using complete sentences and it completely answered the question in using the correct format. Here is another well-written, well-thought out answer:

A) poisonous gasses: the gases can cause multiple diseases; most gasses are flammable.

B) Global weather change: the gasses emitted from the coal fires are mainly greenhouse gasses and they cause the earth to become hotter.

(Table 15)

Table 15. Scoring Rubric for 2-point Open Response Question.

\begin{tabular}{c|c} 
Points & Criteria \\
Earned & \\
\hline
\end{tabular}




\begin{tabular}{|l|l|}
\hline 0 & $\begin{array}{l}0 \text { points means no answer was given or answer does not make coherent } \\
\text { sense related to the question. }\end{array}$ \\
\hline 1 & $\begin{array}{l}1 \text { point means the answer began to address the question but was } \\
\text { fragmented or contained an incomplete thought. } \\
\text { OR }\end{array}$ \\
& $\begin{array}{l}\text { The answer only contained one sentence (the instructions for all open } \\
\text { response questions are to use "at least two complete sentences"). }\end{array}$ \\
\hline 2 & $\begin{array}{l}\text { 2 points means both the question was answered adequately and } \\
\text { succinctly. }\end{array}$ \\
\hline
\end{tabular}

Question \#13: What are agencies like the EPA doing to combat the environmental impact of coal fires?

This question addressed learning the learning objectives Environmental Impact of Coal Fires, Human Health Impact of Coal Fires, and Extinguishing Coal Fires.

\section{(Graph 3)}

Graph 3: Percentage of Points Earned: Question 13

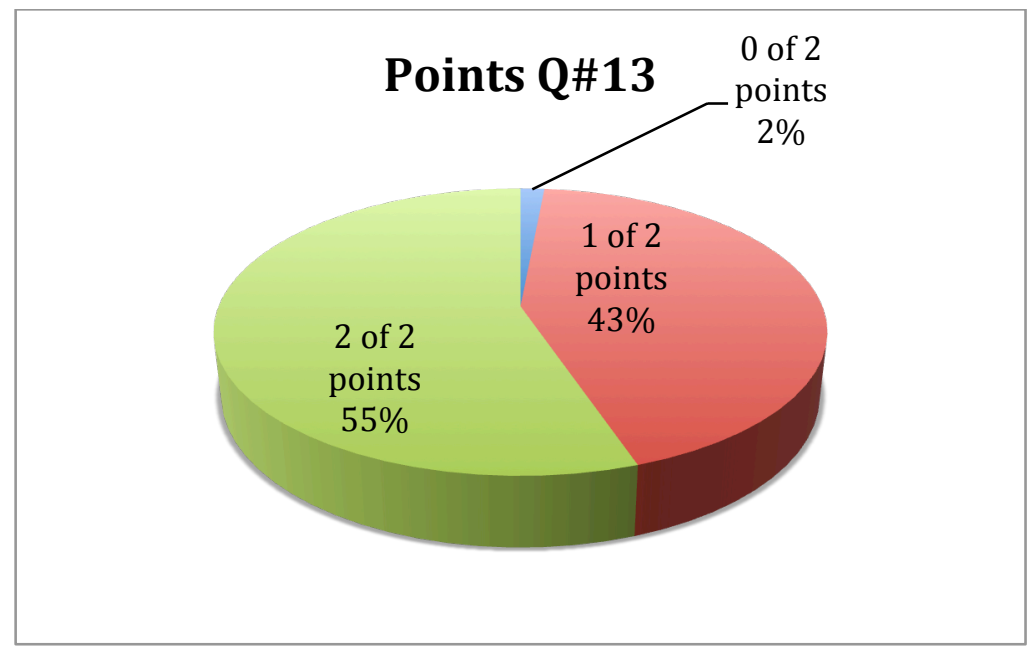

Again, I was disappointed to find that one student left the question blank. However, the remaining students answered the question. 
Scoring a question that is only worth two points posses a new dynamic in grading. I attempted to train my students throughout the year to answer questions completely. The standing rule in class was that it took at least two complete sentences to accomplish this. Additionally, the instructions on this test delineated at least two complete sentences for each open response question. For the questions that had multiple parts it should have been intuitive that the student use more than one sentence to answer. However, for this particular question, they had to follow the directions specifically to gain full credit.

It is worthy to note however, that if a student did happen to completely and fully answer the question with one, long, detailed sentence, then that response could earn $2 / 2$ points.

The following is an example of a 1/2-point answer:

They are trying to help stop the fires, and they are trying to stop mining in general. They are trying to bring new methods around to stop fires.

The first sentence in this answer was incorrect. The EPA was certainly not trying to stop all coal mining. This portion of the response received no credit. However, I was able to award one point for the second sentence mentioning that the EPA was attempting to discover new ways to extinguish or control coal fires.

When evaluating an answer like this, one that is only a 2-point open response, it is often important for the instructor to view the answer from the standpoint of what it is not, rather than what it is. In other words, the instructor should read an answer like the one above and consider whether or not this answer deserves zero credit. Most educators would concede that this example is not a zero-credit answer, and it is certainly not a full- 
credit, 2-point answer, so the only legitimate grade for this is $1 / 2$ points. Using a grading rubric like the one above, along with this type of assessment logic, makes it easier for an instructor to award fair and legitimate grades.

Another example of a $1 / 2$ points answer:

Making sure it is properly sealed and the area is clean.

This student didn't use two complete sentences, so my first thought in grading this was that it had the possibility of earning $1 / 2$ points. As I read the answer, it was a valid thought, although not fully answering the question, and of course not using two complete sentences as the directions instructed, so it was quickly determined that it would be awarded $1 / 2$ points.

These answers that earn $1 / 2$ points show that the student has gained a good understanding of the concept. In this case, there was a range of learning objectives that applied to the question. For the students to be able to offer an answer of this quality, they had to have learned about how coal fires impacted the environment. Their answers showed that understanding was gained, but not completely solidified for them. If they had offered a more detailed answer that demonstrated a complete understanding, they would have been able to earn two points. However, their answers showed that they did gain legitimate understanding.

A little less than half of those tested were the $1 / 2$ category, which again can encompass a broad range of understanding. So, I was not too disappointed in the results.

The results demonstrated that more than half of the students were able to supply a $2 / 2$ point answer; $55 \%$ of students gained full credit for this question, showing that they 
were able to either use two complete sentences that fully address the issue, or one very detailed sentence that completely tackles the topic. Here are some examples:

The EPA is trying to stop and extinguish coal fires. They

already put small coal fire out from creating a foam

substance that stops it from still burning.

And also:

The EPA is trying to come up with ways to put out the fire,

for example using foam to take away the oxygen from the

fire.

These examples show how one student wrote two sentences and correctly answered the question, while the second student wrote one sentence and yet still completely answered the question. Both of these answers show student learning and the capability of expressing those answers. They both discussed a valid point -- that the EPA was attempting to extinguish fires and was researching new methods of the same.

(Table 16)

Table 16. Scoring Rubric for 5-point Open Response Question.

\begin{tabular}{|c|l|}
\hline $\begin{array}{c}\text { Points } \\
\text { Earned }\end{array}$ & Criteria \\
\hline 0 & $\begin{array}{l}\text { 0 points means no answer was given } \text { or answer does not make coherent } \\
\text { sense related to the question. }\end{array}$ \\
\hline 1 & $\begin{array}{l}1 \text { point means the student attempted to answer the question using } \\
\text { terminology and ideas that were discussed in class, but lacks significant } \\
\text { comprehension or understanding. }\end{array}$ \\
\hline 2 & 2 points means two parts of the question was answered adequately. \\
\hline 3 & $\begin{array}{l}\text { 3 points means only three parts of the question were answered. } \\
\text { OR }\end{array}$ \\
\hline 4 & $\begin{array}{l}\text { More than three parts were answered but there was a significant lack of } \\
\text { substantiated evidence supporting those answers. } \\
\text { and adequate synthesis of thought. }\end{array}$ \\
\hline
\end{tabular}




\begin{tabular}{|c|c|}
\hline & OR \\
& One part of the question was not answered. \\
\hline 5 & $\begin{array}{c}5 \text { points means all four parts were answered adequately and succinctly } \\
\text { and the response shows thoughtful and intelligent answers. }\end{array}$ \\
\hline
\end{tabular}

Question \#14: What efforts are being made to extinguish coal fires in Kentucky? Are they working? Why or why not?

This question addressed learning the learning objective Extinguishing Coal Fires. (Graph 4)

Graph 4: Percentage of Points Earned: Question 14

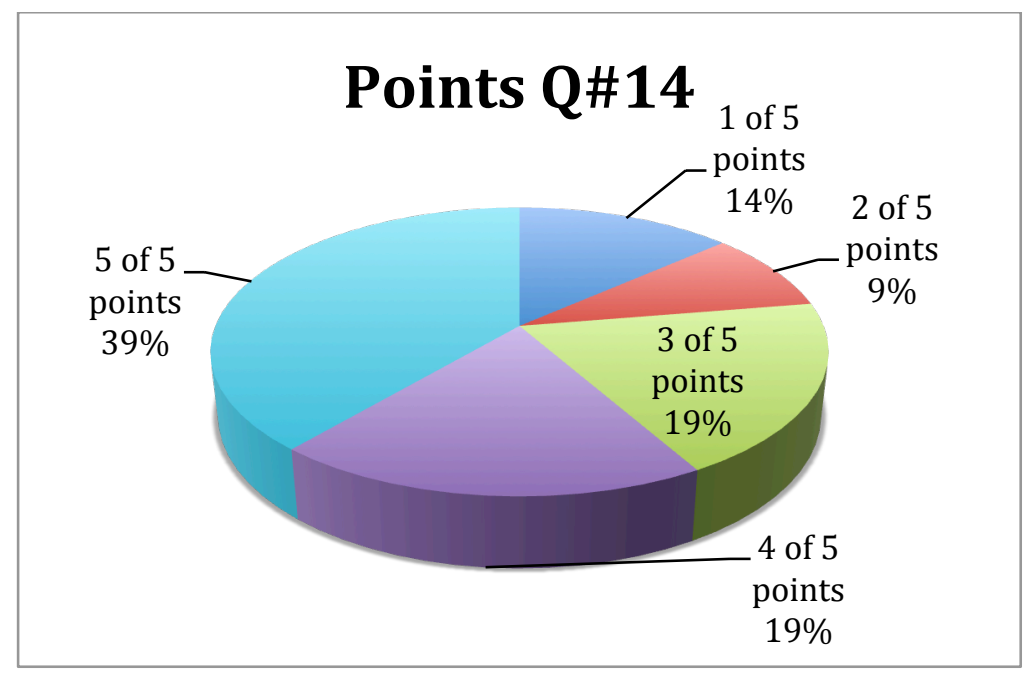

A significant number of students scored in the $4 / 5$ or $5 / 5$ point range. Also, there were no students that left this question blank. I always wrote the point value directly on the test for each open response question. That way students always knew exactly how they would be graded, and it also gave them a very good idea how much writing they should expect to gain full credit.

When scoring a multi-part answer like this one, I always give one point if the student gives a worthy effort. This encourages students to at least attempt to put down 
something even if they are not very confident of their answer. So, when scoring this, it is a 5-point answer because one point is for attempting. This helps to teach students to not skip answers and leave them blank; they get rewarded for a serious attempt.

Here is an example of a 1/5 points answer: They are trying to move the coal fires away from other coal fires. No, these are not working because they can still catch on fire from the heat. This answer shows that the student did not comprehend that you cannot move a coal fire. A response like this indicates that the student lacks a concrete understanding of coal seams, coal fires, and the mining process in general. It is obvious that the student knew that she studied coal and that coal catches on fire, but beyond that, she did not demonstrate any practical application proving deeper knowledge.

A 2-point answer showed a slightly deeper grasp of concepts than a 1-point answer, as demonstrated below:

Digging them up. No, because it takes too much manpower. This student earned 2 points for two reasons. He was correct that one process in which coal fires are being extinguished is by digging them up and spreading out so they burn themselves out. Also, it is not effective because it is too work- and time-intensive. So, these both were valid points, therefore earning 2 points.

However there was no depth of knowledge demonstrated in this answer. I could have stretched my grading rubric and tried to give him 3 points for this answer based on the idea that he actually gave an answer for each specific question, e.g 1-efforts, 2-are they working, and 3-why or why not. However, this answer did not show thoughtful insight concerning the topic. I could only justify 2 points for this answer.

Here is another noteworthy 2-point answer: 
People are trying new ways to put out coal fires in

Kentucky, but they are not working because it is expensive and very hard to extinguish.

This answer had a couple of good points which earned it's score. I couldn't award 3 points because there was some misinformation in this answer. In fact, there actually are methods that are working to extinguish coal fires whereas the student said that there were not. The student certainly had a more thoughtful and better-worded answer than the previous example, but with the bit of mistaken facts, his score was limited to 2 points.

Moving on to the range of scores that are considered passing, e.g. $60 \%$ or more. Answers earning three points and above needed to show extended application of understanding instead of simply being able to list at least two facts concerning coal fire extinguishment. A good example follows:

Many agencies are trying their best by using a foam substance that smothers the fire but it hasn't put all of them out yet.

This answer was a longer sentence but showed a complete thought and the student was able to express it in a more mature fashion.

And again:

They have tried water but it's not working because things

like steam explosions happen making things worse.

This answer takes the approach of methods that were tried but did not work. He explained what was tried, whether or not it worked, and exactly what the problem was to make this method ineffective. I was again caught between whether or not to grade this as a two- 
point or a three-point answer solely based on the idea that he only wrote one sentence, but as it was a better-constructed and more mature answer, I was inclined toward the higher grade.

Using the rubric criteria, a 4-point answer should stand out above the previous examples by showing a deeper grasp of concepts.

They use foam stuff and suffocate the fire out of the mine.

Yes, they are working because the foam is very cold and won't burn with fire.

With one error of fact in this answer, she barely missed earning a 5/5-point grade. The foam that was being used to extinguish coal fires did not accomplish its task because it was cold. This style of thinking is a very common misconception in science classes. At first glance, it appeared as if she knew why the foam extinguished the fire, as stated in the first part of the answer, when she wrote that foam suffocates the fire. But then she demonstrated that she truly did not have a deep understanding of the science behind the process by answering the second part related to the foam being cold. This was a good example of a student who memorized a concept but could not ultimately apply the knowledge beyond her own scientific misconception. Another 4/5 example was:

They are using a new foam method. They spray foam into the mine and it goes out after a while. This is not dangerous because the foam doesn't react with anything hardly.

This was a great and scientifically thorough answer. It shows a very technically accurate comprehension. However, there was one part of the question that was not addressed: She did not express whether or not this is a very effective method. Yes, she said that the fire 
"goes out after a while," but to earn a full five points the student should have explained a deeper understanding of the efficacy of this method, and I didn't see that in her answer.

There were more 5-point answers than any other category. I am always pleased

when I can award full credit for answers when students demonstrate a full and thoughtful effort. One outstanding answer was:

They were using water to put coal fires out trying to drown the fires. Didn't work. They tried using earth on the coal fires to smother it. It worked sometimes. But now they're using this foam that increases its strength and it suffocates the fire.

This was a very comprehensive answer, well planned and well executed. There was no question whether or not this answer demonstrates authentic learning and application of knowledge. This student certainly showed a flair for capturing an idea and expressing it in a way that conveyed a thought and yet expressed a scientific concept.

Here is one last example of a quality 5-point answer demonstrating valid learning.

Old: water

New: foam, digging the mine out

Water did not work. Foam is working fairly well. Digging the top of the mountain works very well. Due to the expense, this is not done often.

This was again a very comprehensive answer. This student showed that she listened and was able to grasp the history of coal fire extinguishing efforts. She even formed a small 
chart showing the old method and the newer methods. Then she described the efficacy of each method, even adding how the financial expense impacts the efforts.

In all, this test showed significant learning from my students in the area of coal fires and coal related information in general. Information from the pretest and from the first classroom discussions indicated that while coal mining was commonplace in our region and most students knew at least a little about the coal industry, many students had never heard of a coal fire and did not understand that there were toxic gasses emitted around the world from coal seam fires and coal emissions. By the end of the unit, many of those same students were able to easily discuss coal fire origins, significant harmful effects on humans and the environment, and even effective and non-effective efforts in controlling and extinguishing them. This was a very successful unit that, I believe, will aid students in applying knowledge and concepts to other situations in the future. 


\section{Chapter 5 - Conclusions}

\section{Overview of Research Results}

The study of coal was an appropriate study for high school students for a number of reasons. Coal itself is a highly prized commodity for energy production of the world and millions of tons of coal are mined worldwide each year. Additionally, coal mining has it's own set of hazards to human health and safety. Finally, the burning of coal, whether intentionally (for the many forms of energy production) or unintentionally (naturally occurring coal seam fires) poses another great hazard to the health of wildlife and humans.

Using this method to teach earth science worked well with students that are accustomed to coal and coal production in their region and culture. It is important that teachers use relevant examples to connect with their students. A student living in California may be able to relate well to the environmental impact of wildfires because of the numerous wildfires that occur in California each year. However, wildfires to not happen nearly as often or as intensely in Eastern Kentucky as they do in California, so a more suitable connection is necessary. This is precisely why an environmental study hinged on the coal industry is very applicable to these students.

In studying coal production and coal seam fires, there were a couple specific ideas that I tried to convey to the students. First and foremost were the environmental and health impacts of coal mining and, more specifically, coal seam fires. I wanted students to know those hazards and also what the coal industry is doing to lessen the impact of those hazards. Coal fires, dangerous mining operations, and coal dust are the main problems. The coal fire problem is addressed through environmental and private agencies 
attempting to extinguish them. The problem of coal dust is primarily a health issue, coal dust being the main factor in the commonly known "black lung" disease of lung cancer. Also, I wanted students to be able to describe a common method of coal mining for the area that we live in, specifically Eastern Kentucky in the area known as the Big Sandy Region. At the time of my research, almost all coal mining in the Big Sandy Region was performed deep underground. The most common method of coal extraction in our surrounding area was called pillar mining, where some of the coal was taken out while some was left under the mountain in large "pillars" for support of the mountain above. It was very hard, dirty, and dangerous work.

Students demonstrated that they learned quite a bit concerning the categories on which they were tested. The data analysis shows that there were many open response questions that were awarded good scores, and many students scored well on tests, which demonstrated a significant portion of my students could authenticate and demonstrate their learning.

\section{Limitations of Research}

Although I feel the unit was successful overall, and enhanced the existing science curriculum at my school, there were some limitations. First of all, I felt that in some ways we had to move through the material too quickly. With existing parameters regarding the topics and amount of material that must be covered each year, the pace of the curriculum is challenging for many students. And though I was able to tie material into required standards, the extra days taken for individual research made it more difficult to get through material in later chapters. However, I feel that the benefit gained from learning experiences throughout the unit outweighed the cost. 
Another limitation was the fact that we were unable to take a field trip and have a more "hands-on" experience as part of the unit. I had originally planned to take the students to the site of a coal seam fire, but was unable to do so due to budget constraints as well as difficulty procuring safety equipment. I feel that seeing the devastation caused by a coal seam fire would have been a life-changing experience, and made the information more real to the students.

Furthermore, a major limitation in the analysis of the data collected throughout the unit was the fact that I failed to use the same pre- and post- test questions. Although I was able to extrapolate the data from similar questions to compare, the synthesis of data would have been more complete and accurate had the students been given the same tests before and after the unit.

\section{Suggestions for Revision}

If I were to use this unit again, or share the materials with another teacher for use in his or her classroom, I would recommend certain changes to enhance the overall effectiveness of the unit. First and foremost, as previously mentioned, I would give the same pre- and post- test to students, so that more accurate data analysis regarding gains in content knowledge could be examined. In looking over the pre- and post- tests that I used, I don't believe that I would choose one to use over the other, but rather I would choose certain questions from each to make a new test instrument.

I would also recommend planning ahead to coordinate a field trip. If plans were made prior to the start of the school year, perhaps funds could be raised, or money allocated from the science budget to accommodate a trip. If we were not able to visit the site of a coal seam fire due to safety issues or lack of safety equipment, perhaps we would 
be able to visit a coal powered plant, or a coal mine. Any time students can experience something first-hand, the learning is more authentic, and likely to become part of longterm understanding rather than rote memorization that will be quickly forgotten. 
Appendix 


\section{Coal Pre-Test}

Name:

Date:

Period:

Multiple choice. For each of the following questions, choose the best or most appropriate answer. Write the letter of that answer in the space provided, or on your answer sheet if one is provided. (correct answer in italics for presentation purposes only).

1) A mining process in which rock is stripped away to expose mineral deposits near the surface is

a) subsurface mining

b) surface mining

c) placer mining

d) undersea mining

2) The most abundant fossil fuel in the world is
a) petroleum
b) natural gas
c) coal
d) crude oil

3) Which describes a way to conserve fossil fuels?
a) Use sandstone instead of granite.
b) Use water saving faucets.
c) Conduct frequent mine inspections.
d) Wash only full loads of laundry.

4) A process that reduces the amount of damage mining does to ecosystems is
a) recycling
b) nuclear fusion
c) subsurface mining
d) reclamation

5) Coal deposits are formed by
a) buried microorganisms in prehistoric oceans
b) fluids moving through impermeable rock
c) carbonization of plant remains
d) burning hydrocarbons burned?

6) What is released in large amounts when coal with a high sulfur content is

a) Sulfur dioxide

b) Carbon dioxide

c) Carbon monoxide 
d) Hydrogen

7) A fossil fuel formed by the remains of prehistoric organisms in shallow oceans and lakes is
a) petroleum
b) lignite
c) coal
d) biomass

8) Fossil fuels consist mainly of
a) methane
b) sulfur dioxide
c) hydrocarbons
d) bacteria

9) Petroleum and natural gas are most often mined from
a) oil shale
b) peat deposits
c) permeable sedimentary rock
d) ore deposits

10) A mineral deposit consisting of many veins within a rock formation is a(n)
a) placer deposit
b) lode
c) ore
d) gemstone

\section{Short Answer}

11. Why must the mining industry be concerned with the Endangered Species Act? 


\section{Article Review Template}

\section{Article Information}

Title:

Author:

Source:

Date:

\section{$\underline{\text { Reviewer Information }}$}

Name:

Date:

Period:

1) Explain what the main idea of the article is.

2) Describe some of the main points that the article brings out that support the main idea of the article.

3) Summarize two new concepts that you have learned from this article related to coal fires.

1)

2) 


\section{Coal and Coal Fire Internet Investigation}

Name:

Date:

Period:

Using a computer with Internet access, search topics related to coal and coal fires to answer the following questions or ideas.

1) What search engine did you use?

2) What were some of the key words used for your search?

3) Define COAL:

4) Define COAL SEAM FIRE:

5) List 3 coal fires that are currently burning in Kentucky. (List their names and locations).

a.

b.

c.

6) List 3 coal fires that are currently burning in places outside the United States (Again, names and locations)

a.

b.

c.

7) Describe two methods of how coal fires get started. 
8) Name and explain two hazards to humans caused by coal fires.

9) What are agencies like the EPA doing to combat the environmental impact of coal fires?

10) What efforts are being made to extinguish coal fires in Kentucky? Are they working? Why or why not? 


\section{COAL \\ Documentary of Appalachia's Coal Miners \\ Season 1, Episodes 1 \& 2 Video Notes}

1) How much roof space to these miners work in? 3-1/2 ft.

2) The "continuous miner" is tipped with tungsten-carbide teeth and takes 1000 volts of electricity to run.

3) It will mine 10 tons of coal per minutes.

4) In the process called "pillar mining", miners cut out 20 ' by 20 ' paths and leave 40 ' by 40 ' pillars for support.

5) Every $20^{\prime}$ by $20^{\prime}$ cut is more than 6 tons of coal and bring in about $\$ 3000$.

6) The term "bad top" in a coalmine means that the top rock is loos and liable to fall, crushing or burying someone.

7) What is the minimum clearance they need for the roof-bolting machine to work? 44 ".

Episode 2 begin 13:00 - to about 17:30

Ventilation and evacuation

1) What are two hazards in the mine if there is no fresh air ventilation? Methane and Coal dust.

2) Is it possible for the mineshaft to catch on fire or have an explosion? Explain. If the methane and coal dust catch fire, there could be a dramatic explosion. 


\section{Article Summary Directions}

\section{DUE:}

Directions:

1) Find and read at least 2 articles discussing coal mining/coal fires and the hazards related to them.

2) Type a paper explaining what you learned from the articles and what the articles discussed.

3) Include one graph or charts that clearly supports your paper. The graph MUST show the negative effects of either coal mining or coal fires, whichever your paper is about! (You can't have a paper that is about coal seam fires and then have a chart that is about the negative effects of coal mining on the environment).

Specifications:

1) Must have 1" margins all around

2) Must use 12pt font

3) Must use TIMES NEW ROMAN font

4) Must be double spaced

5) Must be a minimum of 400 words

6) Must cite your sources

7) Must copy/paste the URL that you got your articles from

IF you would like to, you can email the document to me at my school email.

$$
\text { (school email was inserted here) }
$$

HOWEVER, you cannot say, "I emailed it, sorry you didn't get it". If I do not receive a paper, you will receive a zero for this assignment. 


\section{Coal and Coal Fires End of Unit Assessment}

Name:

Date:

Period:

Multiple choice. For each of the following questions, choose the best or most appropriate answer. Write the letter of that answer in the space provided, or on your answer sheet if one is provided. (correct answer in italics for presentation purposes only).

1) One of the common complaints concerning coal is that when it is burned for energy it emits many undesirable products into the air. Which of the following is a process used to lessen the amount of undesirable products?

e) synthetically creating a coal substitute.

f) washing and drying coal before burning

g) mining coal with cleaner equipment

h) finding coal seams in cleaner areas of the world

2) The underground smoldering of a coal vein or coal deposit is properly referred to as (a)

e) coal smolder

f) coal bed fire

g) coal seam fire

h) coal smoke

3) Coal fires are a problem

e) throughout the world

f) only in America

g) only in Europe

h) only in mountainous regions

4) TRUE or FALSE: It is possible for coal to spontaneously combust.

5) The oldest recorded coal fire on record, which is in New South Wales, Australia, has been burning for more than years.
e) 2
f) 20
g) 200
h) 2,000

6) The leading country of the world in coal production is

e) Russia

f) China

g) The United States

h) Mexico

7) The leading country of the world in coal reserves is 

e) Russia
f) China
g) The United States
h) Mexico

8) Most of the coal fires burning today are the result of

e) spontaneous combustion

f) natural occurrences (i.e. lightning)

g) human activity

h) all three processes

9) Compared to the heat output of coal, wood is

d) much higher

e) much lower

f) about the same

10) Coal fires emit toxic gasses into the environment, which include

e) carbon monoxide

f) methane

g) mercury

h) all of these

\section{SHORT ANSWER/ESSAY QUESTIONs}

Answer the following question in at least two complete sentences. Be sure to discuss ideas and topics you have learned in class and through your own reading and Internet investigation when answering.

11) Describe two methods of how coal fires get started.

a)

b)

12) Name and explain two hazards to humans caused by coal fires.

a) 
b)

13) What are agencies like the EPA doing to combat the environmental impact of coal fires?

14) What efforts are being made to extinguish coal fires in Kentucky? Are they working? Why or why not? 


\section{UNIT PLAN}

\section{Topic}

The topic of this lesson is coal fires and their impact on the environment.

\section{Objectives}

By the end of this lesson students will be able to:

1) create a diagram that shows the coal formation cycle

2) compare and contrast the current process of coal mining with the method of coal mining at the turn of the century

3) organize a chart, graph, or table showing the toxic or hazardous products of combustion from coal fires and their effects on the human body

4) summarize the processes that are currently employed to extinguish coal fires

5) evaluate the efficacy of these processes by examining two agencies which are actively involved in controlling and/or extinguishing coal fires

A chronological breakdown of the assignments and time allotted to each part of the lesson is as follows:

- Class period 1: Introduction to the topic of coal with information regarding coal's utilization in residential settings as well as commercial settings. It is important, especially in Appalachia, for students to know how and where coal is mined. Also, many of my students relatives are, or were, coal miners. However, in this particular school, there are also several students who were not born and raised in Appalachia, so it is good for them to learn about this very important local industry. This first class period will be an introduction to coal mining. 
- Students will watch segments of two episodes of a documentary of modern day coal mining called "COAL". There is a follow-along video worksheet to use during the video.

- Classwork for class period 1: Students will fill out the video worksheet during the video segment of class. This document is found in the Appendix labeled "Coal: Documentary of Appalachia's Coal Miners"

- Homework for class period 1: Each student will be given an article to read tonight. This will prime them to be ready to engage in the classroom activity related to article reviews.

- Class Period 2: Information pertaining to coal fires will be introduced through literature and documents.

- Students will be split into groups and given copies of different research and documentation concerning coal and coal fires in Kentucky and surrounding states. Each group will be given different articles. Each group will then take turns sharing the information with the class as an introduction to coal and the topic of coal fires. Students will get up in front of class and give a short summation of their articles. Furthermore, each group will ultimately be responsible for creating a typed summary of their article as part of the final assessment process. The written summaries will be one- or two-page documents that should be easily completed in a couple of days and ready to be handed in by the end of the unit. This document will include a diagram or chart delineating the effects that the products of coal combustion have on the human body. 
- Classwork for class period 2: Students will fill out the "Article Review Template" during class for this assignment. This will help guide the students in their learning from the coal fire articles.

- Homework for class period 2: Begin typing the article summary that will be handed in at the end of this lesson. This is an assignment that students will complete in addition to regular daily assignments.

- Class Period 3: Coal fire research on the Internet. This will take one class period. For this activity students will be given the document "Coal and Coal Fire Internet Investigation". They will have the entire class period in the computer lab to research coal and find the answers to each question on this handout. (This document is found in the Appendix: "Coal and Coal Fire Internet Investigation")

- Students will be taken to the computer lab and allowed to research a topic or idea that caught their interest from the sharing time the previous day. They will be able to print or write down ideas and websites for future research and writing. The final project of this unit is a research paper compiled by either a student alone or by a pair of students that are given specific research topics related to their report. This portion of the lesson is where they will gain the resources to write and compile their papers outside of class time.

- Classwork for class period 3: Students will use the worksheet mentioned above to fill out during the class period. Anything that they do not finish in class should be completed at home on their personal computer or in the school library when available. Any student that cannot complete the 
assignment at home due to lack of computer availability will be given opportunity to complete it at school during a specially scheduled time.

- Homework for class period 3: Students are to continue working on their article summaries if they have not finished them. Also, students should begin work on their research papers, utilizing the information that was gained in today's computer research.

- Class Period 4: Review concepts related to coal formation. Students native to Russell Independent Schools have had some exposure to information about coal formation in previous middle school classes, so this will be a review for most students rather than an introduction.

- Class notes will be given regarding coal formation. Technology that will be utilized for this lesson are overhead notes that will be shared using using a document camera as well as information that will be viewed by students using the classroom computer.

- Class Period 5: Watch a video segment about coal fires and present classroom instruction related to environmental impact of coal fire emissions.

○ Video: National Geographic "Built For Destruction: Wildfires" has a great segment about coal fires. We will begin class with that video, along with a fill-in note sheet that goes along with it. (NOTE: So far I have not been able to secure a copy of this video nor another good video from National Geographic named "Underground Inferno". If I cannot gain a copy of either of these videos I will find and choose a different video later.) 
- After the video is over, I will spend some time giving some more specific details about how coal fire emission gasses effect the environment and people in our area.

- Class Period 6: Students review in class the information that they have learned throughout this lesson and prepare for a short assessment tomorrow covering coal fires, emission gasses, and their effect on the environment.

- Class Period 7: The assessment during class (the quiz) will be ten multiple-choice questions and one short answer/essay question. This will account for half of the points awarded for the coal fire unit. The other half of the assessment points will be for the report that was assigned at the beginning of this unit. This reports is due today right before the quiz. 


\section{References}

Bauer, S. (2006, September 11). Coal seam fires. Retrieved from

http://www.coalfire.org/index.php?option=com_content\&view=article\&id=21\&I temid $=44$

CAFSCO Fire control believes foam can extinguish coal fire. (2012, May 12). Retrieved from http://standardspeaker.com/news/company-foam-can-quell-mine-fire-

\subsection{6\#ixzzloSbkwkQq}

Cray, D. (2010, July 23). Deep underground, Miles of hidden wildfires rage. Time, 1-3. Retrieved from http:/www.time.com/time/health/article/0,8599,2006195,00.html.

Daldry, S. (Director). (2011). COAL [Documentary]. United States: Netflix.

DeKok, D. (1986). Unseen danger: a tragedy of people, government, and the Centralia Mine fire. Philadelphia: University of Pennsylvania Press.

Dixon, T. W., \& Chesapeake \& Ohio Historical Society. (2006). Chesapeake \& Ohio in the coal fields of West Virginia and Kentucky: Mines, towns, trains. Clifton Forge, VA: Chesapeake \& Ohio Historical Society.

EH-93-4 The Fire Below: Spontaneous Combustion in Coal. (1993, May). The Office of Health, Safety and Security - Home. Retrieved January 4, 2011, from http://www.hss.energy.gov/publications/esh_bulletins/BULL0094.html

Hower, J., \& O'Keefe, J. (2010). The fire that keeps burning. CAER Energeia, 21(5), 1-3.

Hower, J. C., Henke, K., O'Keefe, J. M., Engle, M. A., Blake, D. R., \& Stracher, G. B. (2009). The Tiptop coal-mine fire, Kentucky: Preliminary investigation of the measurement of mercury and other hazardous gases from coal-fire gas vents. 
International Journal of Coal Geology, 80, 63-67.

doi:10.1016/j.coal.2009.08.005.

Kolker, A., Engle, M., Stracher, G., Prakash, A., Radke, L., Schure, A., \& Hefferen, E. (2009, September). Emissions from coal fires and their impact on the environment. USGS Publications Warehouse. Retrieved from http://pubs.usgs.gov/fs/2009/3084/pdf/fs2009-3084.pdf Kuenzer, C. (2007, March 23). Coal fires. In Encyclopedia of Earth. Retrieved from http://www.eoearth.org/article/Coal_fires

Morton, M. C. (2010, May 5). Hot as hell:Firefighting foam heats up coal fire debate in Centralia, Pa. Earth Magazine. Retrieved from http://www.earthmagazine.org/article/hothell-firefighting-foam-heats-coal-fire-debate-centralia-pa.

O'Keefe, J. M., Neace, E. R., Lemley, E. W., Hower, J. C., Henke, K. R., Copley, G., . . . Hatch, R. S. (2011). Old Smokey coal fire, Floyd County, Kentucky: Estimates of gaseous emission rates. International Journal of Coal Geology, 87, 150-156. doi:10.1016/j.coal.06.005.

O'Keefe, J. M., Henke, K. R., Hower, J. C., Engle, M. A., Stracher, G. B., Stucker, J. D., . .. Drew, J. W. (2010). CO2, CO, and Hg emissions from the Truman Shepherd and Ruth Mullins coal fires, eastern Kentucky, USA. Science of the Total Environment, 408, 1628-1633. doi:10.1016/j.scitotenv.2009.12.005.

Ohlson, K. (2011, January 4). Earth on fire. Discover, 1-4. Retrieved from http://discovermagazine.com/2010/jul-aug/28-earth-on-fre. Rubinkam, M. (2010, February 5). Centralia, the Pa. village above burning coal seam, is down to 5 houses. Associated Press. 
Rutherford, F. J., \& Ahigren, A. (1990). Science for all Americans. New York: Oxford University Press.

Stracher, G., Finkelman, R. B., Hower, J. C., Pone, D. N., Prakash, A., Blake, D. R., .. . Schroeder, P. A. (2009, September 22). Natural and anthropogenic coal fires. In Encyclopedia of Earth. Retrieved from http://www.eoearth.org/article/Natural and anthropogenic coal fires

Stracher, G. B., Prakash, A., \& Sokol, E. V. (2010). Coal and peat fires: A global perspective. Amsterdam: Elsevier Science.

Stracher, G. B. (2007). Geology of coal fires: Case studies from around the world. Boulder, Colo: Geological Society of America.

Torok, G. D. (2004). A guide to historic coal towns of the Big Sandy River Valley. Knoxville: University of Tennessee Press.

Wiske, M. S. (1998). Teaching for understanding: linking research with practice. San Francisco: Jossey-Bass Publishers. 